\title{
Taphonomic patterns of a dinosaur accumulation in a lacustrine delta system in the Jurassic Morrison Formation, San Rafael Swell, Utah, USA
}

\author{
Janet Bertog, David L. Jeffery, Katherine Coode, William B. Hester, \\ Rath R. Robinson, and John Bishop
}

\begin{abstract}
The Upper Jurassic Brushy Basin Member of the Morrison Formation is widely accepted as having accumulated in a semi-arid meandering stream/floodplain ecosystem. However, in central Utah, the lower Brushy Basin Member is interpreted to be an enclosed inland fresh water lake with a river delta forming its easterly margin. The Aaron Scott Quarry fauna includes numerous dinosaurs as well as typical semi-aquatic taxa such as turtles and crocodiles and provides a unique opportunity to study the taphonomy of a fluvio-deltaic lacustrine setting in the Jurassic. We interpret that during a period of drought numerous animals congregated on the delta as other localized watering holes dried up. Over time, their carcasses accumulated, were broken up, abraded and reworked by a variety of biological and physical agents before final burial. Preferential alignment of the fossil bones suggests two flow directions: the distributary channel flowing off the delta and a wave-induced current at 90 degrees to the channel. The bones are distributed in a layer about $1 \mathrm{~m}$ thick. The bones at the base are highly fragmented and abraded while those higher in the bed belong to a single individual of a diplodocid sauropod. Numerous Allosaurus teeth are associated with the diplodocid bones and may have been shed during repeated scavenging by several Allosaurus.
\end{abstract}

Janet Bertog, Department of Physics and Geology, Northern Kentucky University, Highland Heights, Kentucky 41099, USA. bertogj@nku.edu

David L. Jeffery, Department of Petroleum Engineering and Geology, Marietta College, Marietta, Ohio 45750, USA. jefferyd@marietta.edu

Katherine Coode, Department of Physics and Geology, Northern Kentucky University, Highland Heights, Kentucky 41099, USA. katherin_coode@usgs.gov

William B. Hester, Department of Physics and Geology, Northern Kentucky University, Highland Heights, Kentucky 41099, USA. archromeo@yahoo.com

Rath R. Robinson, Department of Physics and Geology, Northern Kentucky University, Highland Heights, Kentucky 41099, USA. RathR@aol.com

John Bishop, Department of Petroleum Engineering and Geology, Marietta College, Marietta, Ohio 45750, USA. jbishop187@aol.com 
Bertog et Al.: TAPHONOMy OF the MORRISON FM.

Keywords: delta; lake; sauropod; dinosaur; taphonomy

\section{INTRODUCTION}

The Jurassic Brushy Basin Member of the Morrison Formation is typically interpreted as a meandering stream floodplain depositional ecosystem, with all the subenvironments associated with such a system (Dodson et al., 1980; Parrish et al., 2004; Turner and Peterson, 2004; Gates, 2005). It is exceptionally rich in vertebrate fossils, with localities being accumulations of multiple organisms (e.g., Bilbey, 1998; Richmond and Morris, 1998; Foster, 2003; Turner et al., 2004; Gates, 2005). These accumulations have primarily been associated with meandering river floodplain deposits including point bar deposits, channel lags, crevasse splays and oxbow lakes (Turner and Peterson, 2004). Drought-induced mass mortalities are commonly used to explain the accumulations in what has been interpreted to be a semi-arid environment (Turner and Peterson, 2004 and references therein; Gates, 2005). Although dinosaur assemblages have been described in deltaic deposits along marine margins and tetrapod assemblages have been described in deltaic deposits along lake margins, especially associated

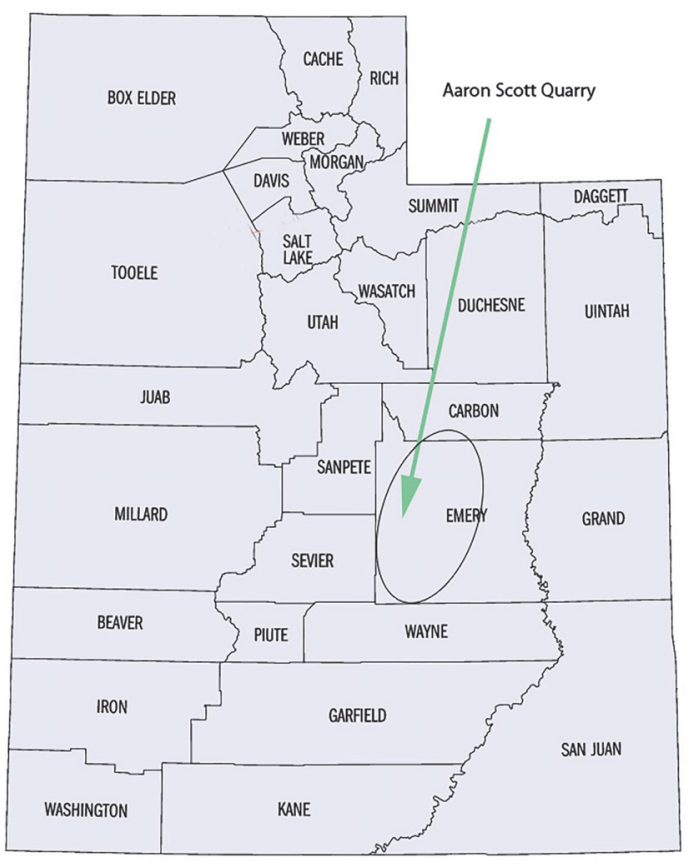

FIGURE 1. General location of the Aaron Scott Site in Emery County, Utah (modified from the US Census Bureau, 2000). with rift basins (Rogers, 1990; Alberdi et al, 2001; Mancuso and Marsicano, 2008; Eberle et al., 2010; Rogers et al., 2001), identification of dinosaur accumulations in deltaic deposits along lake margins are rarely identified.

Stratigraphic studies of the Aaron Scott Site (Figure 1) in central Utah indicate that this site was located on a delta along the margin of a large inland lake (Jeffery et al., 2011). Previous studies of the Morrison Formation indicate that groundwater fed marshlands occur (Turner and Peterson, 2004) and carbonate lacustrine environments have been described in lowlands, especially in Colorado (Jackson, 1979; Lockely et al., 1986; Dunagan, 1998; Dunagan and Turner, 2004). The wellexposed strata of the Brushy Basin Member at the Aaron Scott Quarry shows patterns consistent with a prograding delta system in which sediments were deposited during the progressive fill of a large lake. Bone accumulations of this sort are previously unrecognized in the Morrison Formation and are rare for vertebrate assemblages in general, and it has been suggested that fluctuations in base level are the major factor responsible for the accumulation and preservation of bones at this site (Jeffery et al., 2011). The occurrence of vertebrate accumulation in relation to this lake basin fill provides a unique opportunity to characterize the taphonomic patterns of a lacustrine delta environment.

\section{BACKGROUND}

\section{Morrison Formation of the San Rafael Swell}

The Morrison Formation is one of the most widespread units bearing vertebrate fossils in the world, extending from Arizona to Montana and from Utah to Oklahoma (Turner and Peterson, 2004). Depositional patterns in the Morrison Formation are controlled by four major structural features: 1) a continental magmatic arc in California and Arizona provided sediment from the west and southwest to the Colorado Plateau (Peterson, 1994), 2) The Elko orogenic belt and highlands in eastern Nevada and Idaho (Peterson, 1994), 3) the ancestral Front Range and Uncompahgre uplifts in southeastern Utah and Colorado provided the majority of the sediment material for the Morrison Formation (Lawton, 1994; Peterson, 1994), 4) the Utah-Idaho trough is genetically related to the Elko highlands and was a subsiding depression during the Middle Jurassic that was inverted to a positive 


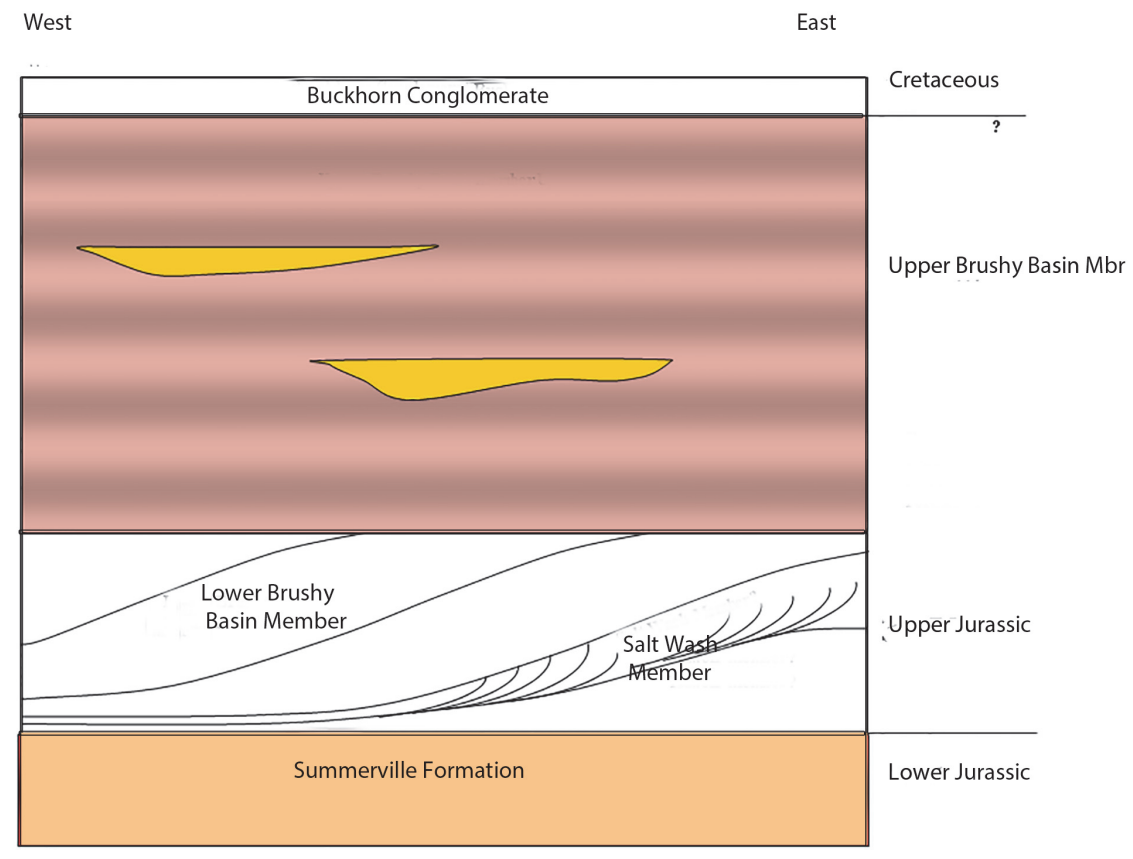

FIGURE 2. General stratigraphy of the Morrison Formation in the vicinity of the Aaron Scott Site.

structure in the latest Middle Jurassic (Peterson, 1994). The formation was deposited during the final regression of the transcontinental seaway during the Jurassic. Individual members are not easily correlated from one region to another.

The Morrison Formation of central Utah is located along the margins of the San Rafael Swell, a broad, asymmetrical Laramide uplift roughly 75 miles long trending northeast and 30 miles wide. The eastern margin is steeply dipping and the western margin is more gently dipping (Stokes, 1986), and eroded into numerous cuestas. Beds dip approximately 5 degrees to the west, although it is difficult to determine how much of this is structural and how much is stratigraphic (Jeffery et al., 2011).

The Aaron Scott Quarry was discovered in 2001 and is located in Emery County, Utah, on the western flank of the San Rafael Sell southeast of the town of Ferron, Utah (Figure 1). The formation in this area has been divided into three members the Tidwell, Salt Wash and Brushy Basin (Figure 2). These units are described in great detail in previous works, including the nearby Cleveland Lloyd Dinosaur Quarry (Dodson et al., 1980; Peterson and Turner, 1987; Bilbey, 1998; Gates, 2005; Hunt et al., 2006). The basal Tidwell Member consists of mudflat, playa and sabkha environments in a transitional depositional environment from the marine
Summerville Formation to the dominantly terrestrial Morrison Formation (Peterson and Turner, 1987). The Salt Wash Member is primarily braided stream and floodplain deposits sourced from surrounding mountain ranges. The Brushy Basin Member consists of a lower gray unit, representing lacustrine environments, that interfingers with the underlying Salt Wash Member and an upper red, gray and green variegated unit representing deposits on a broad, flat alluvial plain consisting of extensive floodplain deposits with ponds and swamps as well as alkaline lakes (Dodson et al., 1980; Demko et al., 2004; Jeffery et al., 2011). Calcareous nodular paleocalcretes are common within the floodplain deposits presenting further evidence of semi-arid conditions (Demko et al., 2004). These calcretes become more common in the upper part of the Brushy Basin Member, where paleosols are more mature and indicate increased seasonality. Most of the alkaline lakes and oxbow lakes and swamps are thought to be shallow (less than $10 \mathrm{~m}$ ) and small (less than $65 \mathrm{~km}$ ) (Dodson et al., 1980). Dodson et al. (1980) recognized that the abundance of calcretes and chert increased upward in the section, representing an increasingly arid environment.

The thickness of the Morrison Formation in this area is problematic because the beds are westward-off lapping wedges that pinch out west- 


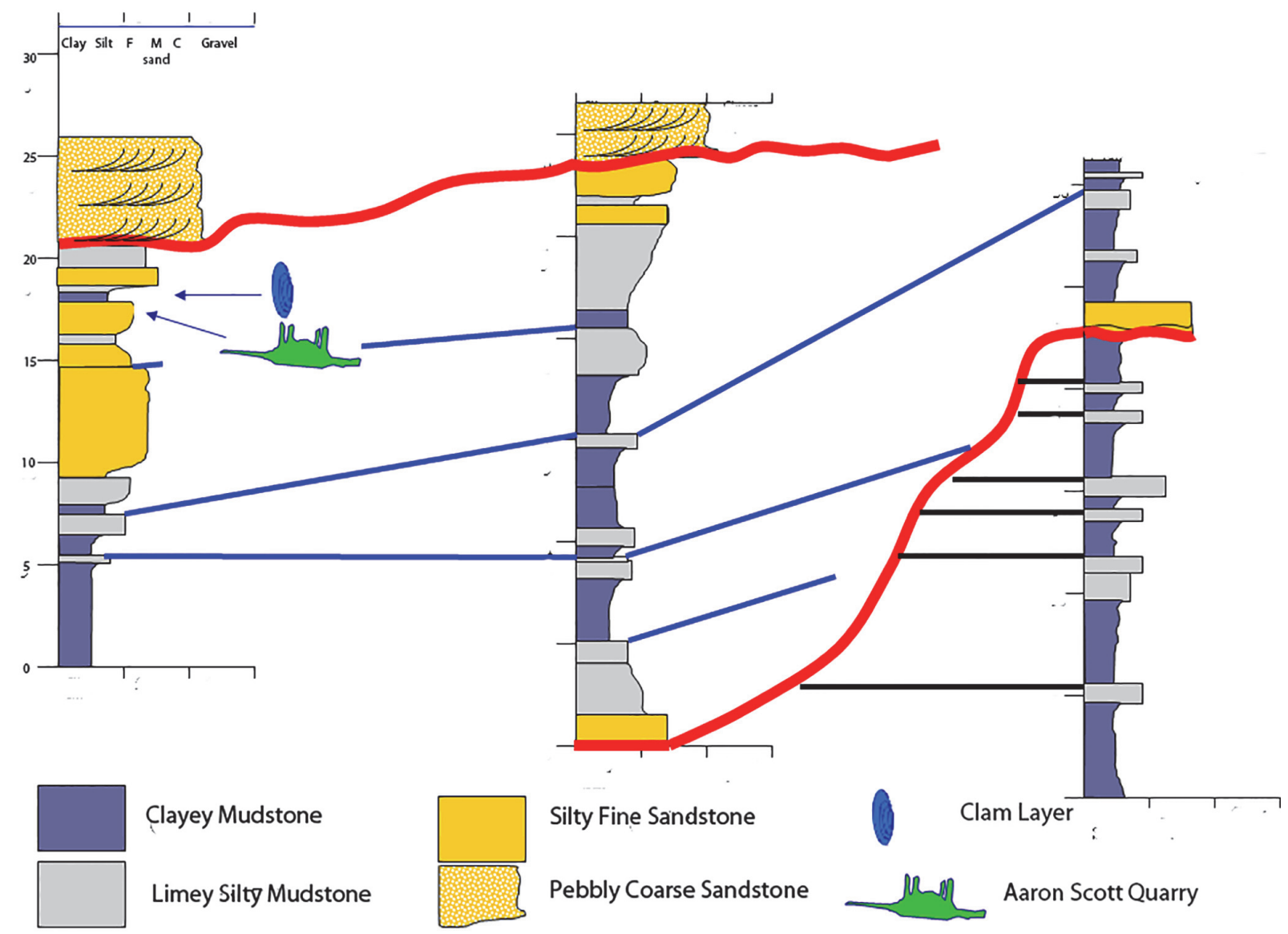

FIGURE 3. Sequence stratigraphy of the Aaron Scott Site, showing the position of the dinosaur bones and overlying Unio clams. Beds coarsen upward and measured sections tend to coarsen upward and westward as well. Erosional truncational surfaces are bold correlation lines while truncated and onlapping bedding are finer correlation lines.

ward and crop out in a broad, north-south belt. The approximate thickness is $30-50 \mathrm{~m}$ from the Summerville to the upper Brushy Basin Member. The upper Brushy Basin is up to $120 \mathrm{~m}$ thick at the site (Vandevelde, 2006). The Aaron Scott Quarry is in the lower Brushy Basin Member.

Stratigraphic data from the Aaron Scott Quarry (Jeffrey et al., 2011) indicate that the quarry locality was on a delta plain along the eastern margin of a lacustrine environment. The quarry exposure is $15 \mathrm{~m}$ by $15 \mathrm{~m}$ and does not represent the entire length of the lake margin. The thickness of the deltaic units indicates $15 \mathrm{~m}$ of accommodation space in the lake (Jeffery et al., 2011), and lake levels fluctuated within this basin depending on climate variations. Tectonic uplift of the Colorado Plateau (Steiner, 1998) could have produced a basin in the area of the San Rafael Swell. Paleomagnetic data show that the Colorado Plateau and the craton show a displacement of the paleopoles during mid-Morrison deposition, which become aligned in the late Morrison deposition, indicating that these areas were tectonically distinct prior to the late Morrison deposition. This is coincident with a hiatus, onset of volcanism, and a change in base level exhibited in the Morrison Formation (Turner and Peterson, 2004).

\section{Sequence Stratigraphy of the Aaron Scott Quarry}

Sequence stratigraphic relationships of lake basin fill have been well documented for their petroleum source rock potential, and consequently their stratal geometries are relatively well known (e.g., Dam and Surlyk, 1992; Oviatt et al., 1994; Carroll, 1998; Carroll and Bohacs, 2001; Keighley et al., 2003). The deposit at this locality is interpreted to have accumulated during a brief, climatically forced regression and subsequent rise of base level during the late stages of an overall regression within the sequence (Figure 3) (Jeffery et al., 2011). This drop in base level was likely the 
result of a temporary drought, which resulted in the drying up of smaller watering holes and the congregation of animals near available water sources such as this lake.

\section{Historical Collections and Morrison Taphofacies}

The Morrison Formation dinosaur fossils have been extensively studied since the 1800s. (see Carpenter et al., 1998; Gillette, 1999; Foster, 2003; Turner et al., 2004). Studies have focused on both individual accumulations of dinosaur assemblages and summaries of published quarry data (e.g., Bilbey, 1998; Richmond and Morris, 1998; Foster, 2003; Gates, 2005). Turner et al. (2004) introduced a series of papers summarizing the sedimentology and paleontology of the Morrison Formation.

One commonality among many sites in the Morrison Formation is that they are mostly multispecific accumulations (Engelmann et al., 2004 and references therein). This has been used as evidence of drought conditions when animals that were generally not gregarious congregated along temporary or permanent watering holes where food was more readily available. The paucity of aquatic fauna such as fish, turtles and crocodiles at many sites has also supported a semi-arid environment with few perennial watering holes. This is in stark contrast to the original interpretation of the Morrison Formation as a deep water lacustrine environment, which at that time was thought necessary to support the large sauropods (Coombs, 1975).

Dodson et al. (1980) and Kirkland (2006) summarized numerous additional sites within the Morrison Formation in and around Utah. Between these two papers, six taphofacies can be discerned. These facies include: 1) channel sandstones, 2) channel levees, 3) floodplain deposits (which will be separated into reducing and oxidizing subenvironments), 4) swamps, 5) alkaline lakes and 6) freshwater lakes. The characteristics of these taphofacies are summarized in Table 1 (available online) and will be discussed further in reference to differences compared to the Aaron Scott Quarry.

The Cleveland Lloyd Site is geographically the closest published site to the Aaron Scott Quarry. The site has been the topic of much debate and has traditionally been considered a predator trap, accounting for the high accumulation of Allosaurus at this site (Dodson et al., 1980). Bilbey (1998) described the lower Brushy Basin Member, where the Cleveland Lloyd Quarry is present, as consisting of drab colored calcareous claystone and mud- stone, accumulating in restricted alkaline ponds or swampy areas. However, Gates (2005) reinterpreted the site as an ephemeral watering hole during a period of drought that became a sustained lake (taphofacies 6) with deposition of a micritic marly limestone. The microstratigraphy of this site is a $1 \mathrm{~m}$ thick calcareous mudstone overlain by micritic limestone that varies from 0.3 to $1.0 \mathrm{~m}$ (Gates, 2005). The mudstone is structureless with a volcaniclastic origin and intraformational clay clasts. There are sandy layers within the mudstone. Hunt et al. (2006) expanded on this idea and suggested that the accumulation of the Allosaurus at this site is a population accumulation that resulted from attrition and accumulation of bones in a standing body of water. This site shares some sedimentologic characteristics with the Aaron Scott Site, although the dominant species is different. Because of the stratigraphic similarity and the geographic position, the Cleveland Lloyd Site is useful for comparison to the Aaron Scott Quarry.

\section{Circum-lacustrine Vertebrate Taphonomy}

Accumulation of bone beds on lacustrine deltas is rare. Nonetheless, Alberdi et al. (2001) summarized three circum-lacustrine bone bed accumulations in the Guadix-Baza Basin of Spain, and Mancuso and Marsicano (2008) summarized four areas of accumulation along a Triassic lacustrine system in Argentina. By combining these two reports, six lacustrine taphofacies can be summarized (Table 2; Figure 4): A) swampy environments on a delta plain with episodic fluvial influence (Alberdi et al, 2001), B) swampy/lacustrine environments (Alberdi et al., 2001), C) deltaic-plains (Mancuso and Marsicano, 2008), D) deltaic fronts (Mancuso and Marsicano, 2008; Alberdi et al., 2001 (described as a fluvio-deltaic setting that is periodically flooded by the lake), E) prodeltas (Mancuso and Marsicano, 2008) and F) off-shore lacustrine (Mancuso and Marsicano, 2008). The lake described by Alberdi et al. (2001) was dominated by vertebrate remains while the lake described by Mancuso and Marsicano (2008) was dominated by plant remains with some fish and very few tetrapod body fossils. This was considered to be a result of water chemistry preventing preservation, as it is evident that tetropods were present based on trace fossils (Mancuso and Marsicano (2008).

\section{METHODS}

Excavations at the Aaron Scott Quarry began in 2001 by Marietta College and was continued 
Bertog et AL.: TAPHONOMY OF THE MORRISON FM.

TABLE 2. Summary of taphofacies recognized in circum-lacustrine environments including 1) swampy environments with episodic fluvial influence, 2) fluvial environments which were periodically covered by lacustrine deposits (fluvio-deltaic), and 3) a swampy/lacustrine environment.

\begin{tabular}{|c|c|c|c|c|c|}
\hline Taphofacies & Example & Sedimentology & Paleontology & Weathering & Transport Groups \\
\hline $\begin{array}{l}\text { Swampy } \\
\text { environment with } \\
\text { episodic fluvial } \\
\text { influence }\end{array}$ & $\begin{array}{l}\text { Huelago-1 } \\
\text { (Albderdi et } \\
\text { al, 2001) }\end{array}$ & \begin{tabular}{|l|} 
Green and gray silts \\
with charcoal \\
intraclasts, \\
cyanobacterial oncoids, \\
root traces. Iron oxide \\
preciptate horizons. \\
Interbedded muddy \\
sand-filled channel \\
bodies with a basal \\
mud pebble \\
conglomeratic sand and \\
silt and clay carbonate \\
beds with incipient \\
pedogenic features.
\end{tabular} & $\begin{array}{l}\text { Gastropods, fish, equilibrium } \\
\text { between identified and } \\
\text { unidentified bone remains, } \\
\text { abundant isolated teeth, } \\
\text { small animals most common, } \\
\text { predator damage, algal crust, } \\
\text { no articulated remains, some } \\
\text { associated remains, } \\
\text { trampling common, } \\
\text { concentrations of bones, } \\
\text { some orientation }\end{array}$ & $\begin{array}{l}\text { Advanced } \\
\text { weathering } \\
\text { stages 1-3 }\end{array}$ & $\begin{array}{l}\text { Appendages }(2.5 \%) \text {, Teeth }(28.87 \%) \text {, } \\
\text { Group III }(1.49 \%) \text {, Group II }(7.13 \%) \text {, Group } \\
1(5.8 \%) \text {, Fragments }(54.35 \%) \text {, Coprolites } \\
(0.64 \%)\end{array}$ \\
\hline $\begin{array}{l}\text { Swampy / lacustrine } \\
\text { environment }\end{array}$ & $\begin{array}{l}\text { Cullar de } \\
\text { Baza-1 } \\
\text { (Alberdi et } \\
\text { al., 2001) }\end{array}$ & $\begin{array}{l}\text { Carbonates and } \\
\text { marlstones } \\
\text { interfingering with } \\
\text { alluvial sediments }\end{array}$ & $\begin{array}{l}\text { Fish, reptiles, rodents, } \\
\text { rabbits, carnivores, } \\
\text { ungulates, some articulated } \\
\text { remains }\end{array}$ & $\begin{array}{l}\text { Most are Stage } \\
0,12 \% \text { in } \\
\text { advanced stages }\end{array}$ & $\begin{array}{l}\text { Appendages }(2.14 \%) \text {, Teeth }(23.92 \%) \text {, } \\
\text { Group III }(5.71 \%) \text {, Gropu II }(6.34 \%) \text {, Group } \\
\text { I }(4.76 \%) \text {, Fragments }(56.44 \%) \text {, Coprolites } \\
(1.22 \%)\end{array}$ \\
\hline Delta plain & $\begin{array}{l}\text { Subenv. A } \\
\text { (Mancuso } \\
\text { and } \\
\text { Marsicano, } \\
2008 \text { ) }\end{array}$ & \begin{tabular}{|l|} 
Medium- to coarse- \\
grained sandstone \\
interbedded with black \\
mudstone and very fine \\
grained sandstone. \\
Sandstone beds are \\
tabular to lenticular with \\
basalt mudstone \\
intraclasts.
\end{tabular} & $\begin{array}{l}\text { Logs, tetrapod footprints, } \\
\text { invertebrate trace fossils, no } \\
\text { bone orientation }\end{array}$ & Most are Stage 0 & $\begin{array}{l}\text { Not directly reported, but skeletons were } \\
\text { mostly articulated and showed no } \\
\text { evidence of sorting }\end{array}$ \\
\hline Deltaic front & $\begin{array}{l}\text { Huescar-1 } \\
\text { (Alberdi et } \\
\text { al., 2001) }\end{array}$ & $\begin{array}{l}\text { White calcareous silt } \\
\text { beds devoid of organic } \\
\text { matter and lamination. } \\
\text { Detrital beds grade east } \\
\text { into a } 3 \text { m thick bed } \\
\text { which also contains } \\
\text { bone remains. This } \\
\text { bed is formed of } \\
\text { stacked lens-like bodies } \\
\text { of gravelly sands. } \\
\text { Planar cross- } \\
\text { stratification occurs } \\
\text { occasionally. }\end{array}$ & $\begin{array}{l}\text { Fish, semi-aquatic birds and } \\
\text { mammals, predominance of } \\
\text { unidentified bone remains, } \\
\text { abrasion and breakages } \\
\text { common, rounding of bones, } \\
\text { no carnivore evidence on } \\
\text { bones (may have been } \\
\text { abraded), densely } \\
\text { concentrated and uniformally } \\
\text { distributed, evident dip of the } \\
\text { bone bed to the west, } \\
\text { preferential orientation of } \\
\text { bones }\end{array}$ & $\begin{array}{l}\text { Stages 2-3 (not } \\
\text { including } \\
\text { fragments) }\end{array}$ & $\begin{array}{l}\text { Appendages }(0.23 \%) \text {, Teeth }(19.76 \%) \text {, } \\
\text { Group III }(0.79 \%) \text {, Group II }(2.54 \%) \text {, Group } \\
\text { I (6.13\%), Fragments }(70.49 \%) \text {, Coprolites } \\
(0.07 \%)\end{array}$ \\
\hline Deltaic front & $\begin{array}{l}\text { Subenv. B } \\
\text { (Mancuso } \\
\text { and } \\
\text { Marsicano, } \\
\text { 2008) }\end{array}$ & \begin{tabular}{|l|} 
Upward caorsening \\
sequence \\
characterized by \\
alternation of tabular- \\
massive siltstone and \\
claystone interbedded \\
with parallel laminated, \\
very fine grained \\
sandstone. \\
Sandstones with \\
current-ripples to \\
horizontal lamination \\
and planar to trough \\
cross-bedded in \\
uppermost coarse \\
grained material
\end{tabular} & $\begin{array}{l}\text { plant fragments, fish body } \\
\text { fossils, tetrapod footprints, } \\
\text { invertebrate trace fossils, no } \\
\text { bone orientation, breaking } \\
\text { common }\end{array}$ & $\begin{array}{l}\text { Stage } 0-1 \text { (not } \\
\text { including } \\
\text { fragments) }\end{array}$ & $\begin{array}{l}\text { Not directly reported, but skeletons were } \\
\text { mostly articulated and only fish and trace } \\
\text { fossils were reported, showed moderate } \\
\text { evidence of sorting }\end{array}$ \\
\hline Prodelta & $\begin{array}{l}\text { Subenv. C } \\
\text { (Mancuso } \\
\text { and } \\
\text { Marsicano, } \\
2008 \text { ) }\end{array}$ & $\begin{array}{l}\text { Dark gray to black } \\
\text { carbonaceous } \\
\text { claystone }\end{array}$ & $\begin{array}{l}\text { Plant debris, conchostrans, } \\
\text { bivalves, insects, scarse } \\
\text { partially articulated fish } \\
\text { remains, no bone orientation, } \\
\text { breaking common }\end{array}$ & $\begin{array}{l}\text { Stage } 0-1 \text { (not } \\
\text { including } \\
\text { fragments) }\end{array}$ & $\begin{array}{l}\text { Not directly reported, but skeletons were } \\
\text { partially articulated and only fish and trace } \\
\text { fossils were reported, showed moderate } \\
\text { evidence of sorting }\end{array}$ \\
\hline Offshore lacustrine & $\begin{array}{l}\text { Subenv. D } \\
\text { (Mancuso } \\
\text { and } \\
\text { Marsicano, } \\
\text { 2008) }\end{array}$ & $\begin{array}{l}\text { Dark gray to black } \\
\text { carbonaceous } \\
\text { claystone }\end{array}$ & $\begin{array}{l}\text { plant debris, insects, } \\
\text { conchostrans, fish, no bone } \\
\text { orientation, breaking } \\
\text { common }\end{array}$ & $\begin{array}{l}\text { Stage } 0-1 \text { (not } \\
\text { including } \\
\text { fragments) }\end{array}$ & $\begin{array}{l}\text { Not directly reported but skeletons were } \\
\text { disarticulated and only fish fossils were } \\
\text { reported, high evidence of sorting }\end{array}$ \\
\hline
\end{tabular}




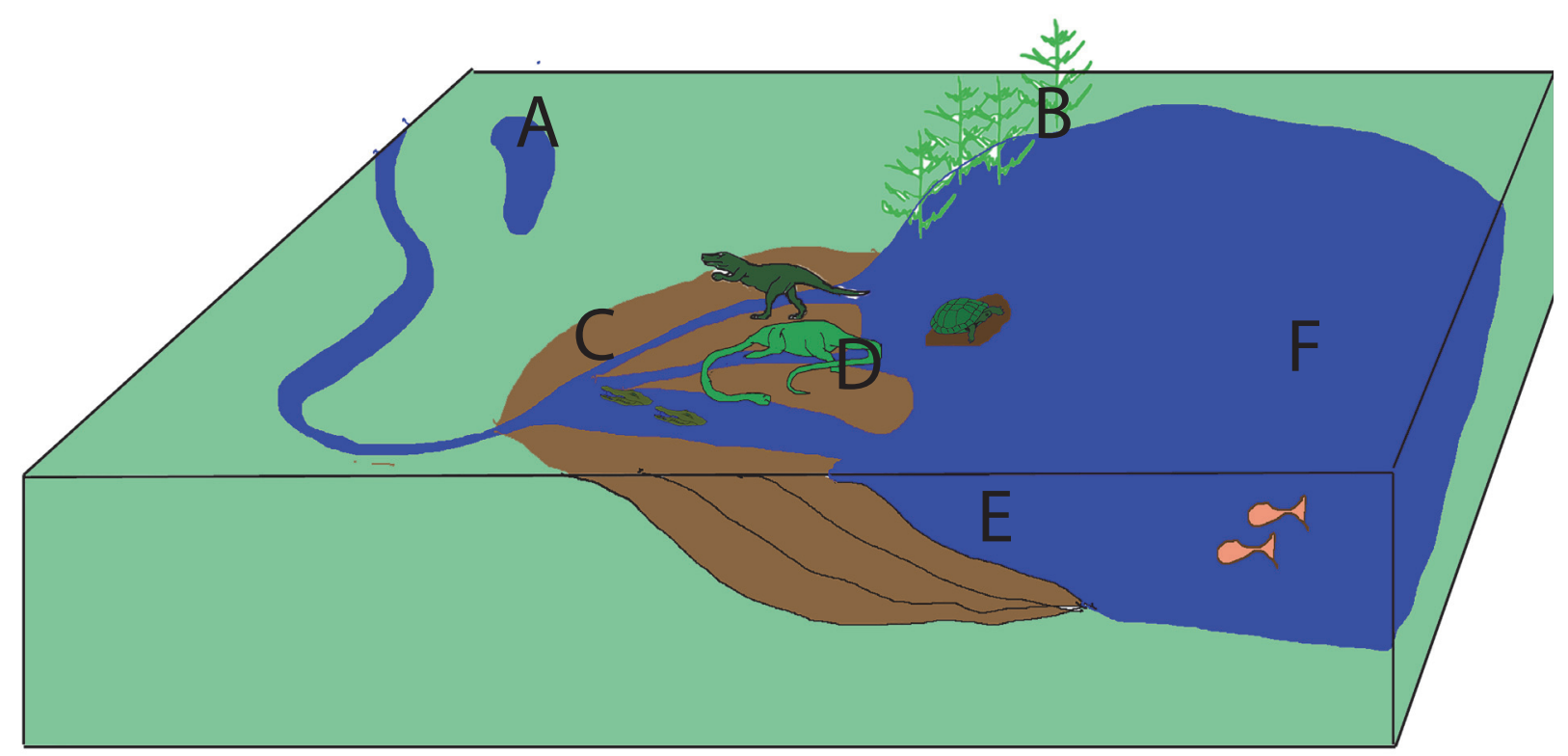

FIGURE 4. Reconstruction of a circum-lacustrine environment combined from Alberdi et al. (2001) and Mancuso and Marsicano (2008) showing the position of the six taphofacies: A) swampy environment with periodic fluvial influence; B) swampy/lacustrine environment; C) delta plain; D) delta front; E) prodelta; and F) offshore lacustrine. The Aaron Scott Quarry is at position D. (Adapted from Mancuso and Marsicano, 2008).

through the field season 2014 by a team consisting of faculty, students and associates from Marietta College, Northern Kentucky University, the University of Cincinnati and the Cincinnati Museum Center. During early excavation, bones were mapped in situ using a traditional grid system using measurements from a datum. Starting in the 2005 field season, bones were surveyed in using a Sokkia Total Station SET610. The $x, y$ and $z$ coordinates and orientation of each bone were digitally recorded with respect to a new datum that was established out of the confines of the known bone distribution as well as being hand sketched onto the overall quarry map. The Cincinnati Museum acts as a repository for all specimens collected during this study. Specimens that have been curated will have the specimen abbreviation CMC VP (Cincinnati Museum Center Vertebrate Paleontology). Specimens that have not been curated will have the specimen abbreviation A.S.S. (Aaron Scott Site).

Data on orientation and position of bones have been plotted using Microsoft Excel and threedimensionally using SAS to show the distribution of bones and groups of bones. Orientation of the bones has been plotted on a rose diagram. Because the sauropod bones lie stratigraphically higher than the other bones and are partially articulated, they will be considered separately from the other bones in the remaining analyses.
Bones were classified into three hydraulic groups based on a combination of Frison and Todd (1986) for sauropod material and Voorhies groups (1969) for non-sauropod vertebrate fossil material. Myers (2007) suggested that elephant bones, with the exception of the skull and mandible, are more comparable in size and density to sauropods. Elephant bones were used for comparison because Frison and Todd (1986) did experiments and established transport groups for elephant bones. It is recognized that sauropod vertebrae and skull elements are dramatically different from elephants. However, Myers (2007) established that the differences, particularly in the vertebrae, were not significant. The number of skull elements is minor in comparison to the overall number of bones, so the presence of skull elements will not dramatically affect the transport group distribution. To further ensure that transport group estimates are accurate, the data were plotted with and without the skull elements (as suggested by Myers, 2007). The distribution groups vary between the elephant bones and the coyote bones, with the sacrum, patella, astragalus, calcaneus and all vertebrae except the atlas in fluvial transport index (FTI) 1; ribs, scapulae, humerii, tibiae and metacarpals in FTI 2; and atlas, mandible, pelvis, radius-ulna and femur in FTI 3 (Table 3) (Frison and Todd, 1986).

Based on distribution of coyote bones in a flume, Voorhies (1969) established three hydraulic 
Bertog et Al.: TAPHONOMy OF the MORRISON FM.

TABLE 3. Voorhie's groups for non-sauropod bones based on data from coyote skeletons (Voorhies, 1969) and Fluvial Transport Index Groups for sauropod bones based on elephant bones (Frison and Todd, 1986).

\begin{tabular}{|c|c|c|c|c|c|}
\hline & \multirow{2}{*}{$\begin{array}{l}\text { Group } 1 \\
\text { FTI }\end{array}$} & \multicolumn{2}{|c|}{ Group 2} & \multicolumn{2}{|c|}{ Group 3} \\
\hline Voorhies & & Voorhies & FTI & Voorhies & $\mathrm{FTI}$ \\
\hline Sacrum & Sacrum & Scapula & Scapula & Mandible & Mandible \\
\hline Vertebrae & Vertebrae (except Atlas) & Humerus & Humerus & Skull & Skull \\
\hline Ribs & & Tibia & Tibia & & Atlas \\
\hline \multirow[t]{7}{*}{ Sternum } & & Metapodials & Metapodials & & Pelvis \\
\hline & Patella & Femur & & & Radius-ulna \\
\hline & Astragalus & Pelvis & & & Femur \\
\hline & Calcaneous & Radius & & & \\
\hline & & Phalanges & & & \\
\hline & & Ulna & & & \\
\hline & & & Ribs & & \\
\hline
\end{tabular}

groups for vertebrate material that can be used to indicate flow velocity based on the elements present - group I includes vertebrae, ribs, and pelvic elements; group II includes limb elements, scapulae and metapodia; group III includes skulls, mandibles, and teeth (Table 3).

The stages of natural weathering and abrasion of bones exposed to a semi-arid floodplain environment have been described (Behrensmeyer, 1978; Fiorillo, 1989). Weathering and abrasion characteristics followed a modification of Behrensmeyer (1978) and Fiorillo (1989) (Table 4).

\section{RESULTS}

\section{The Bone-Bearing Interval}

The stratigraphy and sedimentology of the site were described in detail by Jeffrey et al. (2011).
The major points are summarized here. Within the Aaron Scott Quarry, the base of the bone-rich interval consists of several beds of fine silty sandstone with mudstone lithoclasts overlain by a calcite cemented siltstone layer that is variable thickness from $3 \mathrm{~cm}$ to $24 \mathrm{~cm}$ followed by silty mudstone with abundant unionid bivalves. The silty mudstone is highly bioturbated by dwelling and locomotion bivalve traces (Pelecypodichnus) and Planolites. The bone bed sandstones are massive and contain few sedimentary structures. The bone beds dip to the west at 11 degrees, slightly higher than the enclosing beds at 5 degrees (Figure 5 ).

Bones of the sauropod and many of the Allosaurus teeth lie stratigraphically near or on top of the calcite cemented siltstone layer while fragmented bones and most of the smaller bones,

TABLE 4. Weathering and abrasion scale of bones.

\begin{tabular}{|c|l|}
\hline 0 & No damage at all. Bone is in near perfect condition, smooth surface with no cracking or breaking. \\
\hline 0.5 & Intermittent stage between 0 and 1. \\
\hline 1 & Bone shows cracking, longitudinal and/or latitudinal congruent to structure. \\
\hline 1.5 & Intermittent stage between 1 and 2. \\
\hline 2 & Flaking on outer most layer, following and/or from cracks. Flakes are still attached to bones on one or more edges. \\
\hline 2.5 & Heavier flaking, flakes easily removed from bone, or flakes fall off bone when the bone is moved. \\
\hline 3 & $\begin{array}{l}\text { Patches of rougher bone on surface, connecting patches In patches, and layers. External bone is missing. Patches of weathering } \\
\text { are shallow. }\end{array}$ \\
\hline 3.5 & Intermittent stage between 3 and 4. \\
\hline 4 & $\begin{array}{l}\text { First stage of advanced weathering. Large sections of flaking, pieces falling from the bone when touched or moved. Rough surface } \\
\text { texture, rounding of cracked edges. }\end{array}$ \\
\hline 4.5 & Intermittent stage between 4 and 5. \\
\hline 5 & $\begin{array}{l}\text { In Situ, the worst specimen to be examined. Virtually unrecognizable, splintered into pieces, breaks easily when moved. Perhaps } \\
\text { undeterminable. }\end{array}$ \\
\hline
\end{tabular}




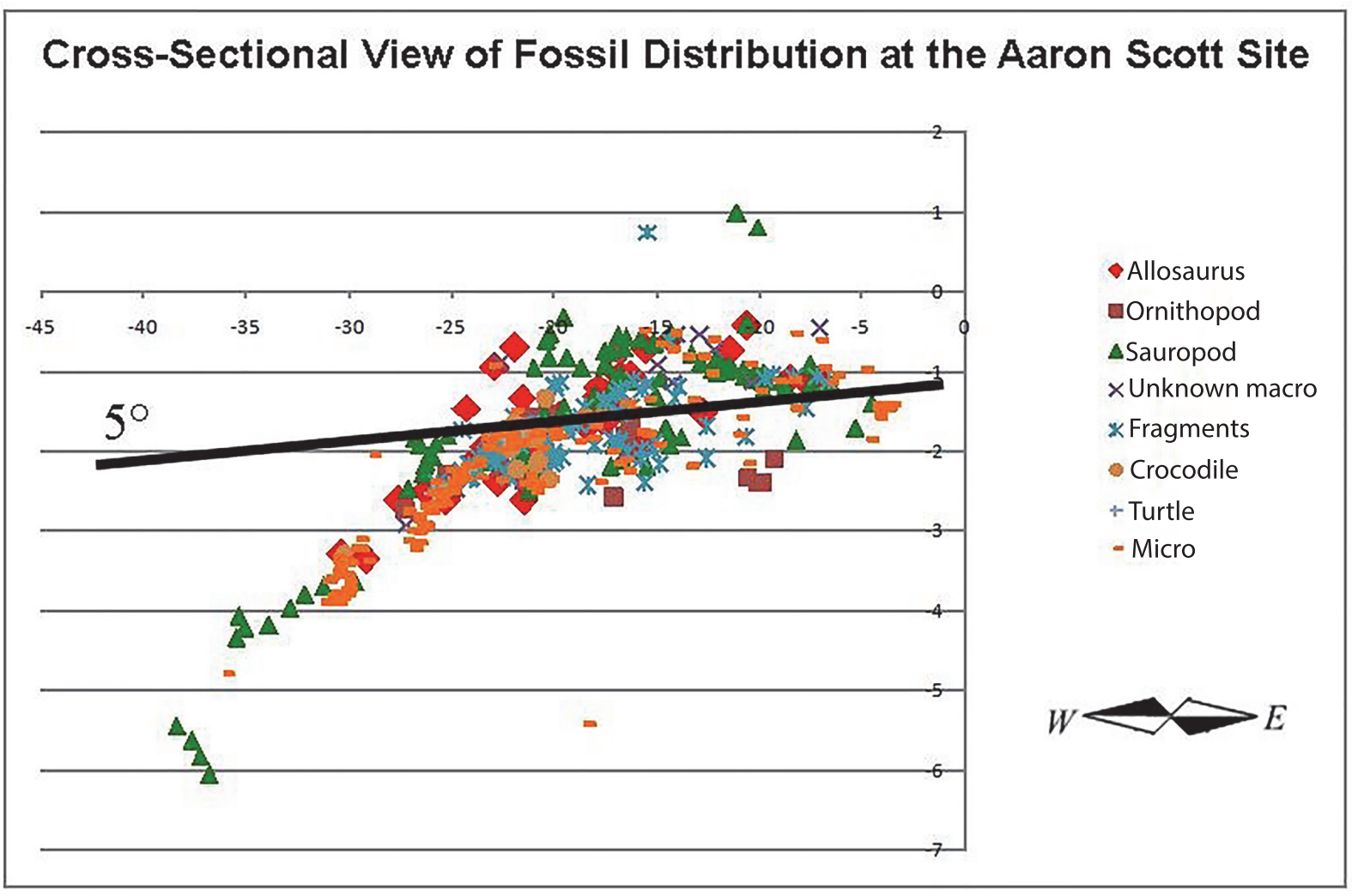

FIGURE 5. Stratigraphic view of the Aaron Scott Site showing the vertical distribution of the bones in the quarry. The diplodocid bones tend to be slightly higher stratigraphically than other bones in the quarry.

including turtle and crocodile, are primarily in the underlying siltstone.

Unionids are only found in the mudstone overlying the vertebrates and not associated directly with the vertebrate material. No other invertebrate material was observed.

\section{Extent of the Quarry}

The quarry is approximately $15 \mathrm{~m}$ by $15 \mathrm{~m}$ (Figure 6). The bone bearing layer is approximately $1 \mathrm{~m}$ thick. Over 1000 bones have been collected representing at least 10 species and 13 individuals. Bones from every part of the body are present, representing multiple taxa.

\section{Fauna}

Esker (2009) first described the fauna of the Aaron Scott Quarry and performed statistical analysis of the site compared to other sites in the Morrison. Although Esker (2009) found no statistical difference in the fauna between the Aaron Scott Quarry and other sites in the Morrison, a combination of paleontology, taphonomy and sedimentology differentiate the quarry from other sites. A taxonomic list is included in Table 5. A partially articulated Barosaurus skeleton dominates the site with isolated Allosaurus teeth associated with this skeleton. Aside from these, turtle and crocodile remains are very abundant, indicating a high proportion of semi-aquatic organisms. The majority of the fauna represented were terrestrial.

\section{Hydraulic Transport}

The Aaron Scott sauropod bones are dominated by partially articulated sections of caudal and cervical vertebrae. Seventy-eight percent of the bones from the sauropod fall in FTI group 1, 17\% were in group 2 and $4 \%$ in group 3 (Figure 7). The majority of the bones in a sauropod skeleton are within group 1 (vertebrae and ribs in particular), while bones from group 3 are primarily isolated teeth and skull fragments. The bones of the sauropod, particularly the vertebrae, show a weak orientation to the west with overall little orientation (Figure 8).

There is an unusually high number of Allosaurus teeth associated with the sauropod. It is thought that the teeth were shed from the Allosaurus whilst it was scavenging the sauropod carcass, and so they were not transported with the other 


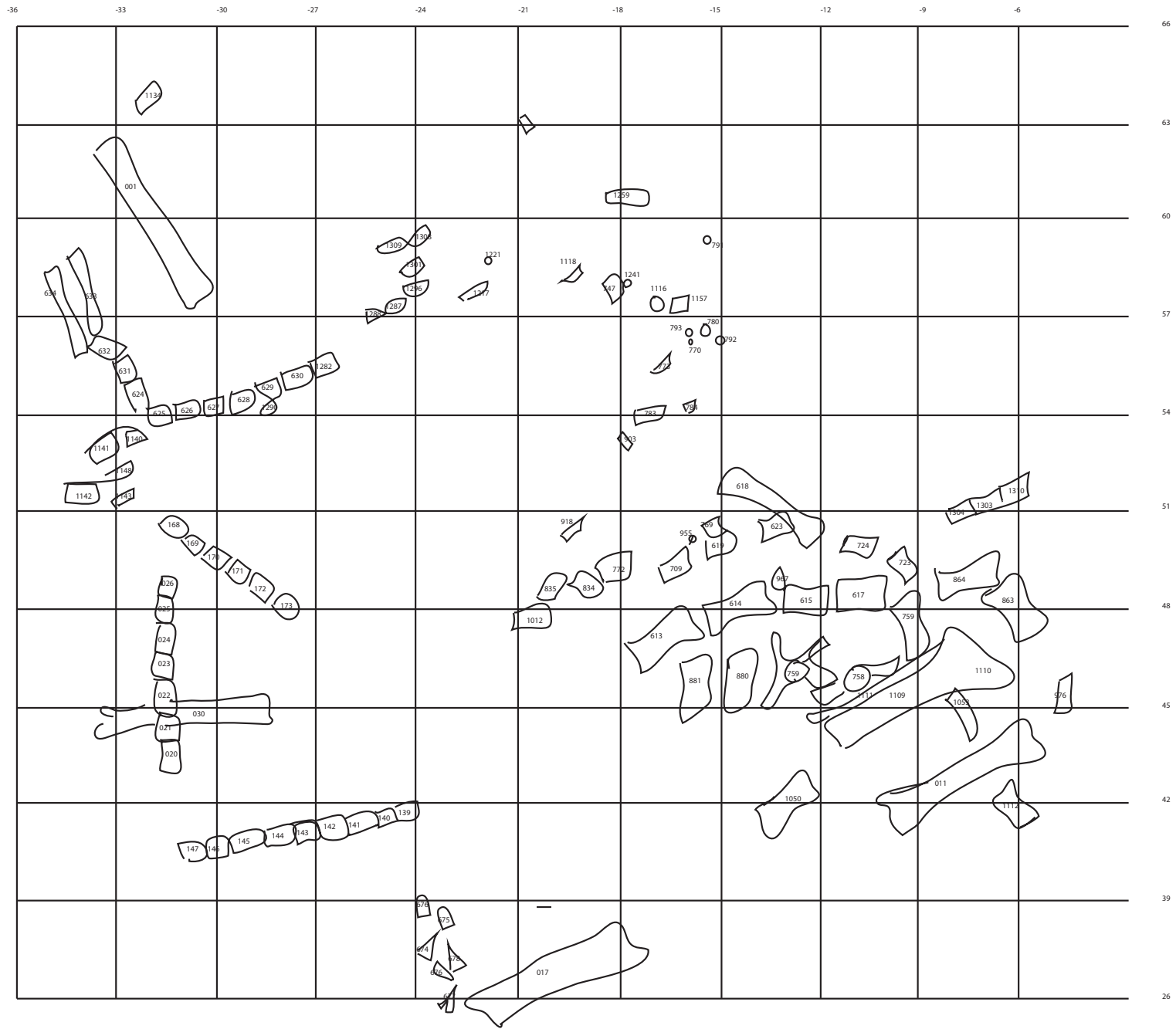

FIGURE 6. Quarry map of the Barosaurus associated skeleton of the Aaron Scott Site showing distribution of the bones collected 2005-2012 in map view.

bones in the quarry. Because of the association of the Allosaurus teeth with the sauropod, they are considered separately from the disarticulated bones. The other bones of the quarry are all disarticulated, fragmented, and many are partially worn. Of the disarticulated non-sauropod bones that are identifiable, $59 \%$ of the bones are from Voorhies group $1,37 \%$ are from group 2 , and $4 \%$ are from group 3 (Figure 9). Thirty-five percent of the bones collected were unidentifiable bone fragments (Figure 10). Comparing this distribution to the distribution of the groups in a typical skeleton (Figure 9), an enrichment of bones from groups 1 and 2 is shown. The non-sauropod bones show a weak orientation that is also primarily to the west with a secondary northwest-southeast orientation (Figure 11).

\section{Weathering and Abrasion}

The bones of the Aaron Scott Site show a range of weathering with an average of 2 , indicating cracking and flaking of the bones (Figures 12, $13,14,15,16)$. There is also a large concentration of bones with a rank of 5 , indicating that the bones were broken into pieces (Figure 14). These bones are typically rounded on the edges due to further transport after fracturing. The sauropod bones are an exception to the highly variable nature of weathering and exhibit no weathering or abrasion (Figure 16). These bones are also partially articulated, and were probably held together by strong ligaments and tendons as well as desiccated skin.

\section{DISCUSSION}

The occurrence of bone bed deposits on a lacustrine delta is unusual in the Mesozoic and this 
TABLE 5. Faunal list of organisms at the Aaron Scott Quarry.

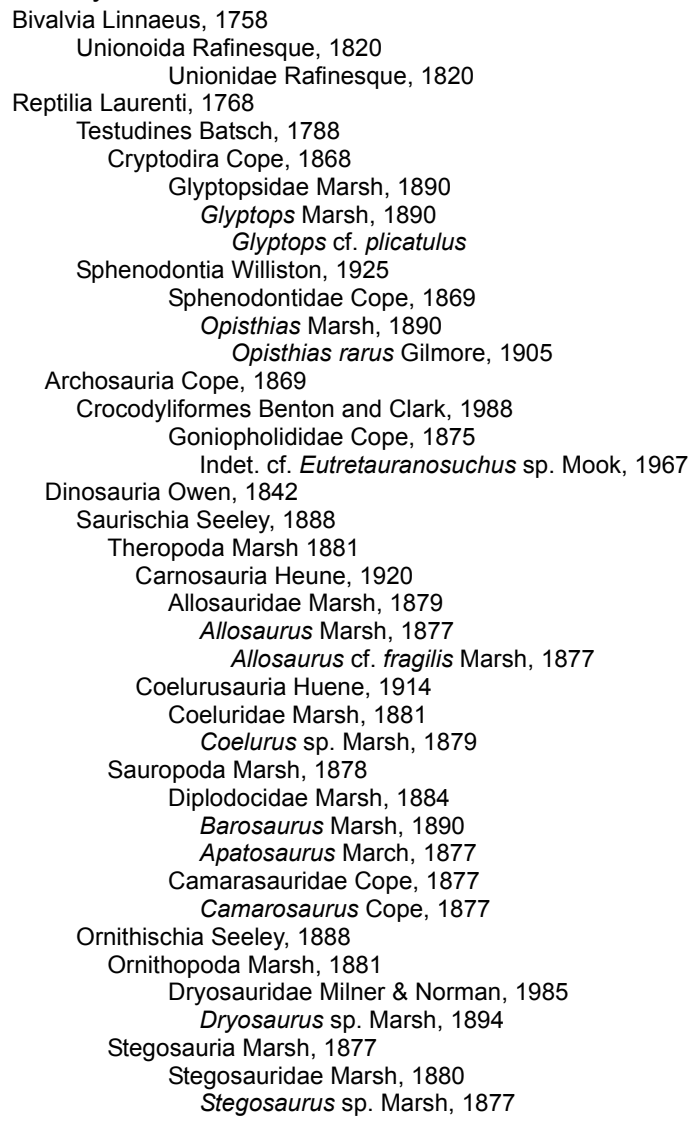

deposit allows for the description and interpretation of the bones in such an environment. The unique taphonomy of the Aaron Scott Quarry is a result of its depositional setting on a lacustrine delta front, making it unique in the Morrison Formation.

The quarry has characteristics that are similar to lacustrine deposits as well as fluvial deposits and indicates that the lake was a perennial lake, unlike most ephemeral bodies of water represented in the Morrison Formation. Furthermore, the taphonomic data indicates that the bones accumulated on the delta over a period of time and does not represent a mass mortality.

The paucity of elements of the sauropod from groups 2 and 3 suggests that the bones were slightly hydraulically separated but are fairly close to that of the overall skeleton (Figure 9). This indicates possibly some downstream transport occurred. The distribution of FTI groups and orientation indicate little transport of the sauropod bones. In addition, the distribution of non-sauropod bones, combined with the disarticulation and abrasion of the bones, suggests an accumulation of bones that are primarily easily transportable. This would be consistent with accumulation at the terminal end of a river, where easily transportable bones are carried.

\section{Comparison to Morrison Formation Taphofacies}

A comparison with established taphofacies of the Morrison Formation (Dodson et al., 1980; Kirkland, 2006) indicates some similarities to other sites but also distinct differences that make this site unique (Table 1).

The Mygatt Moore and Cleveland Lloyd quarries represent ponds or oxbow lakes (Dodson et al., 1980). The microstratigraphy of the Aaron Scott Quarry is similar to the Cleveland Lloyd site, with a siltstone overlain by a calcite cemented siltstone (Gates (2005) describes the calcite cemented siltstone as limestone). This is also similar to the Mygatt-Moore Quarry, except that the MygattMoore Quarry does not have the overlying calcite cemented siltstone (Kirkland and Armstrong, 1992). They are considered ephemeral because they lack an aquatic fauna such as crocodiles and turtles that are expected in a sustained body of water. Taphonomically, the Aaron Scott Quarry is similar to the Cleveland Lloyd site. In both cases, a mass accumulation is dominated by Voorhies' group 1 bones (easily transported bones), but includes all three groups. Most of the bones at both sites are disarticulated, but some bones show some degree of association. The bones show a slight degree of orientation, generally indicating a southwest current at the Cleveland Lloyd site and generally a west-southwest current at the Aaron Scott Quarry. Cross-beds in the sandstones also indicate a westerly current.

There are, however, differences between the Cleveland Lloyd site and the Aaron Scott Quarry. Although the microstratigraphy of the two sites is similar, the overall stratigraphy at the Aaron Scott Quarry indicates a prograding delta into a nearby lake. The entire succession consists of coarsening upward units of mudstone and siltstone in a sigmoidal pattern in cross-section that thickens and then thins down depositional dip, massive sandstones lapping onto the pinchout up-depositional dip, and the repeating progradational pattern within dozens of beds in a $15 \mathrm{~m}$ vertical succession (Figure 3). The bones within the succession dip at a higher degree than the overall structural dip of the enclosing strata (Jeffery et al., 2011). Taxonomically, the Cleveland Lloyd site is dominated by Allosaurus and only one crocodile tooth has been 


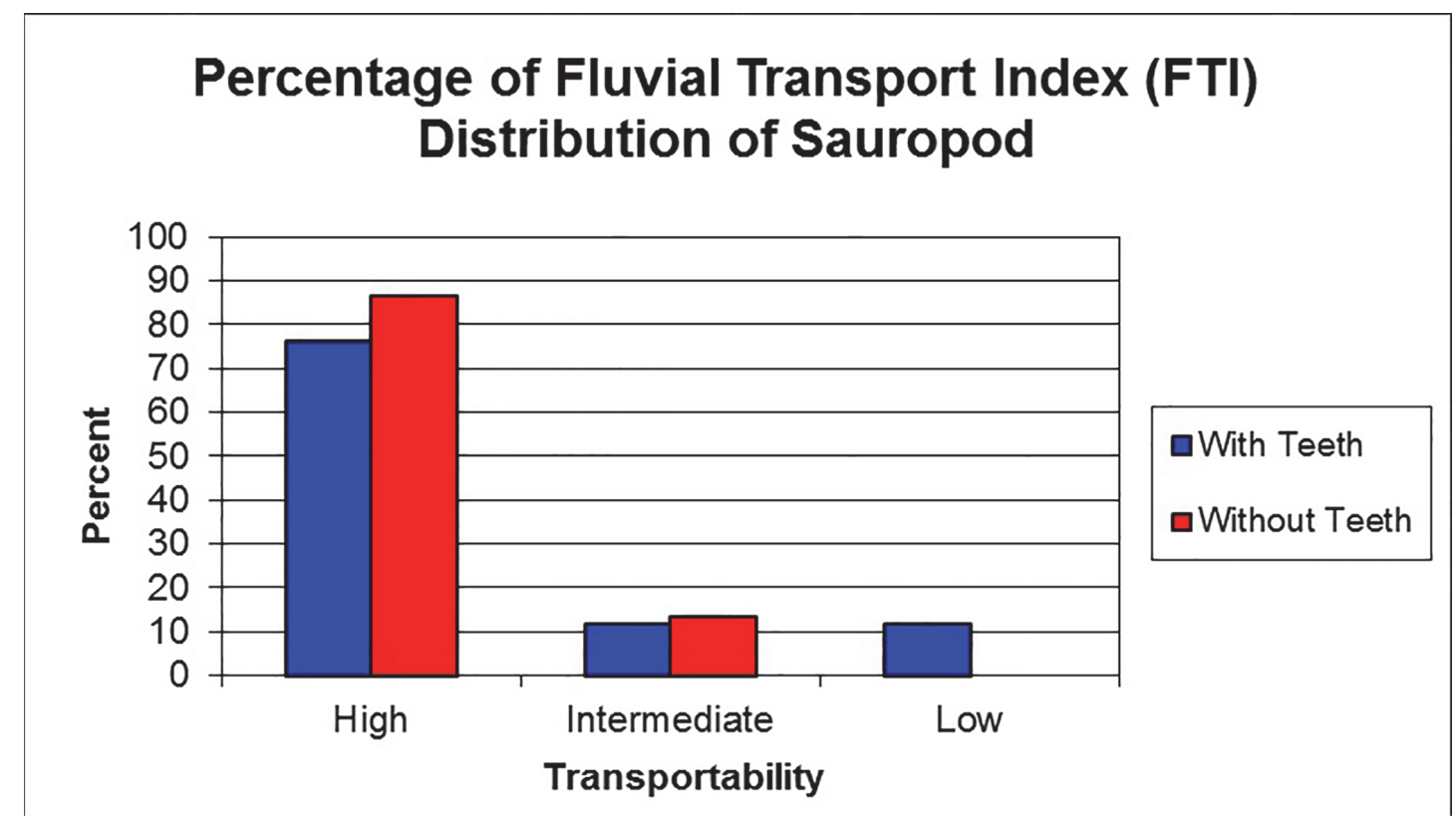

FIGURE 7. A distribution of the bones of the diplodocid based on FTI groups (Frison and Todd, 1986).

found (Gates, 2005). At the Aaron Scott Quarry, Allosaurus teeth are common but it is not the dominant genus, and turtle and crocodile remains are common. Taphonomically, the Cleveland Lloyd site has a low range of weathering stages with most bones exhibiting no weathering and the highest weathering stage being a 2 (Gates, 2005) while the Aaron Scott Quarry has a full range of weathering

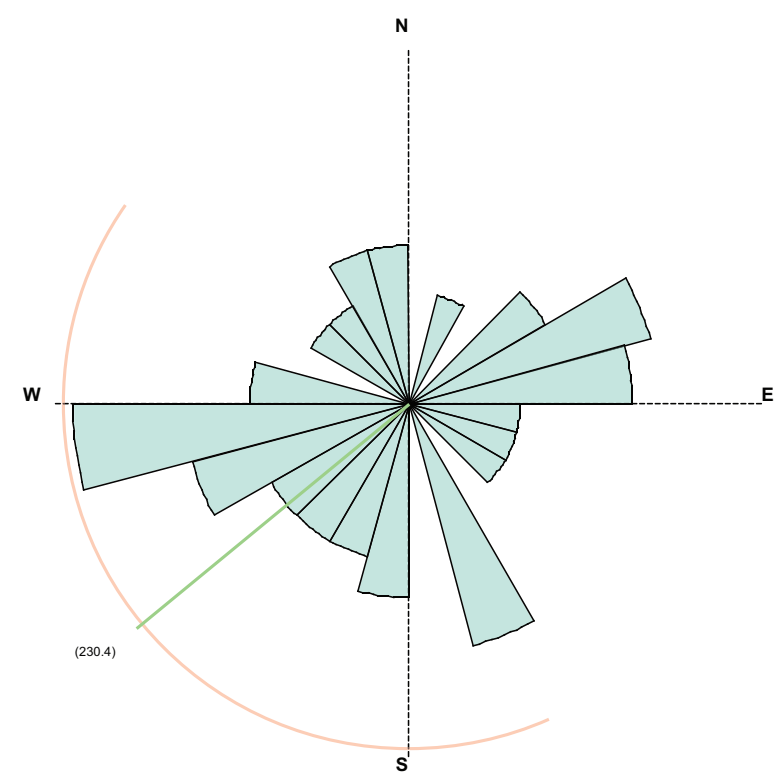

FIGURE 8. Rose diagram showing the orientation of the sauropod bones. A poor bimodal distribution is indicated, with one set of bones oriented to the west and a second set oriented northwest-southeast. from 0 to 5 and bone clasts - broken, rounded bone fragments - are common. Microfauna are not reported at Cleveland Lloyd while they are common at the Aaron Scott Quarry.

\section{Comparison to Other Delta-lacustrine Settings}

Sedimentologically and taphonomically the Aaron Scott Quarry most closely resembles a delta front taphofacies (Albedi et al., 2001; Mancuso and

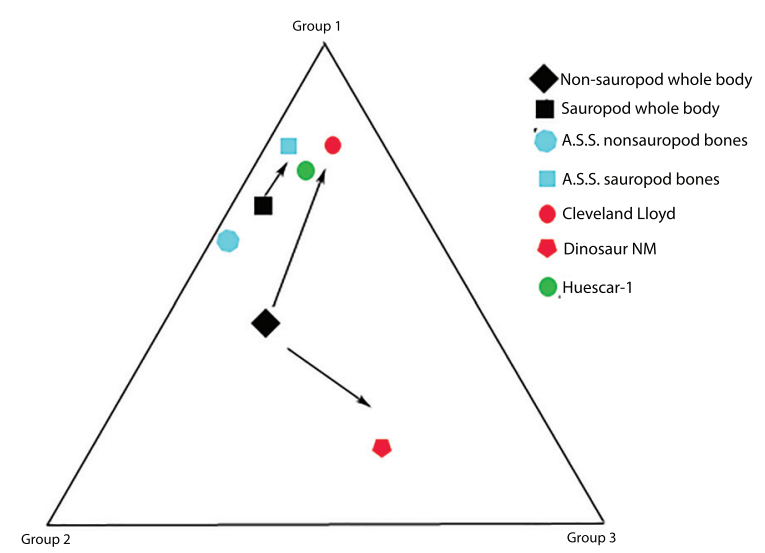

FIGURE 9. Ternary diagram showing the expected bones of a complete sauropod skeleton and the path of enrichment that bones would take if they were transported from their source compared to if they were enriched at the source. Bones of the sauropod indicate an enrichment in group 1 bones, suggesting a terminal transport deposition of the bones. 


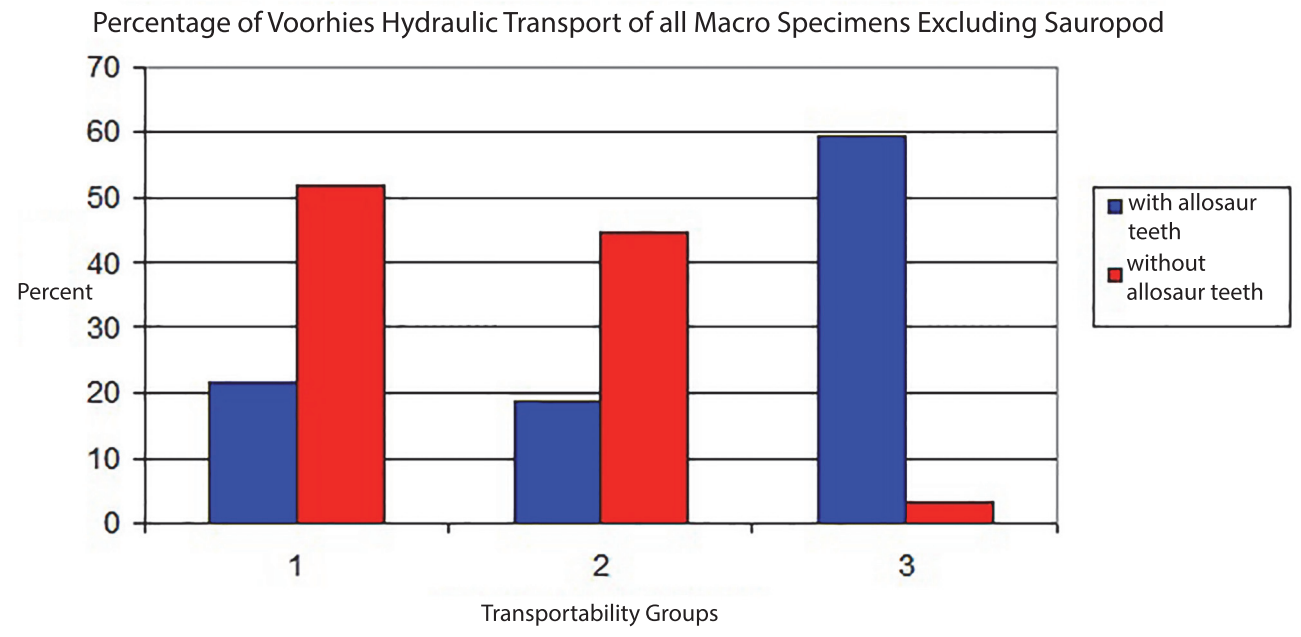

FIGURE 10. A distribution of the non-sauropod bones on Voorhie's groups. The bones were plotted with and without the Allosaurus teeth because the abundance of Allosaurus teeth suggest that the Allosaurus was feeding on the sauropod and that the teeth were not transported into the area. Excluding the Allosaurus teeth, the bones show an enrichment of group 1 bones, suggesting a terminal transport deposition of these bones.

Marsicano, 2008), particularly the Huescar-1 deposit of Alberdi et al. (2001) (Table 6). Beds dipping at an angle higher than the structural dip of the strata indicate a depositional dip that would be consistent with a delta front dipping into the lake and is seen in both Huescar-1 (Albedi et al., 2001) and the Aaron Scott Quarry. Bones typically show a slight orientation as a result of reworking from the

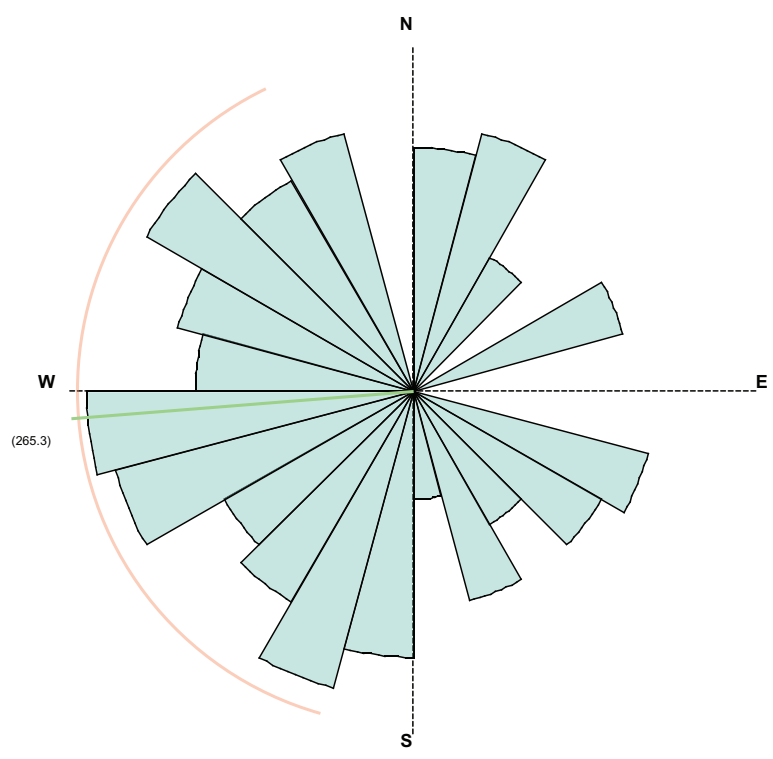

FIGURE 11. Rose diagram showing the orientation of the non-sauropod bones. The distribution of these bones shows very weak orientation, but does indicate a bimodal distribution with one set oriented to the west and a second set oriented northwest-southeast. fluvial input of the delta. Bones are densely concentrated and uniformly distributed in all three cases representing a delta front environment. With the exception of numerous bone fragments, the bones show a range of weathering from 0-5 but have an average of about 2. Voorhies' groups 1 and 2 are dominant as a result of downstream transport and accumulation near the terminal end of the river. Differences in the taphonomic signature of the delta front taphofacies of Los Rastros Formation are attributed to water chemistry conditions that prevented the preservation of abundant vertebrate remains.

\section{CONCLUSION}

1. The fossil-bearing unit at the Aaron Scott Quarry can be divided into three layers: 1) A calcite cemented sandy siltstone with mud ripup clasts. The layer consists of mostly disarticulated bones, including bones of turtle and crocodile. The disarticulated bones indicate that the bones were exposed for a period of time. Bones that are easily transported hydraulically are dominant, indicating that the bones are accumulating near the deltaic end of a river. The bones exhibit a range of weathering from 0-5 (Behrensmeyer, 1982), indicating that the bones were exposed over a period of time ranging from less than a month to six months or more (Behrensmeyer, 1982) with some being exposed to weathering longer than others. The bones exhibit a bimodal ori- 


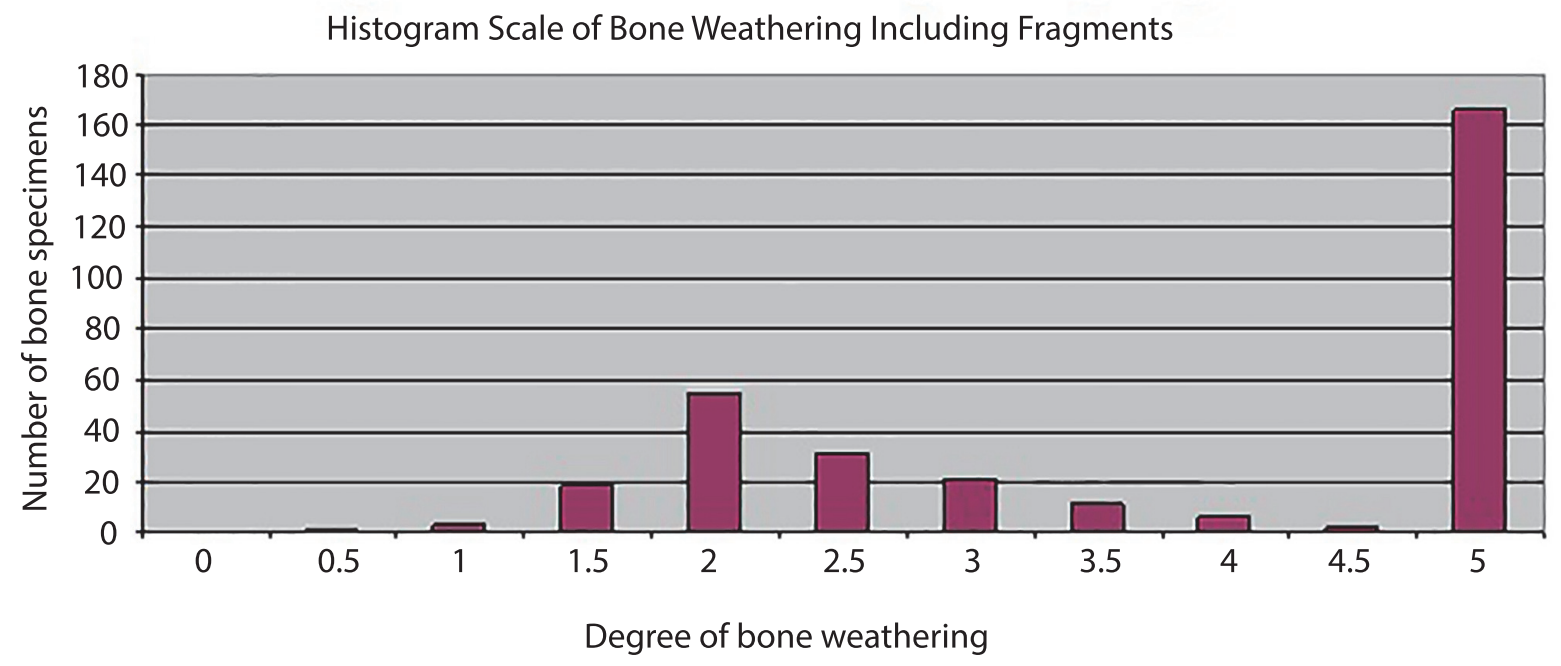

FIGURE 12. Histogram of bone weathering and abrasion for non-sauropod bones (sauropod bones had weathering of zero and are not included on this diagram). Weathering rank of 2 indicates flaking and cracking of the outer layer of the bone and is the most common in non-fragmented bones. Fragmented bones are ranked as a 5 , indicating that the bones have broken apart and may have been rounded

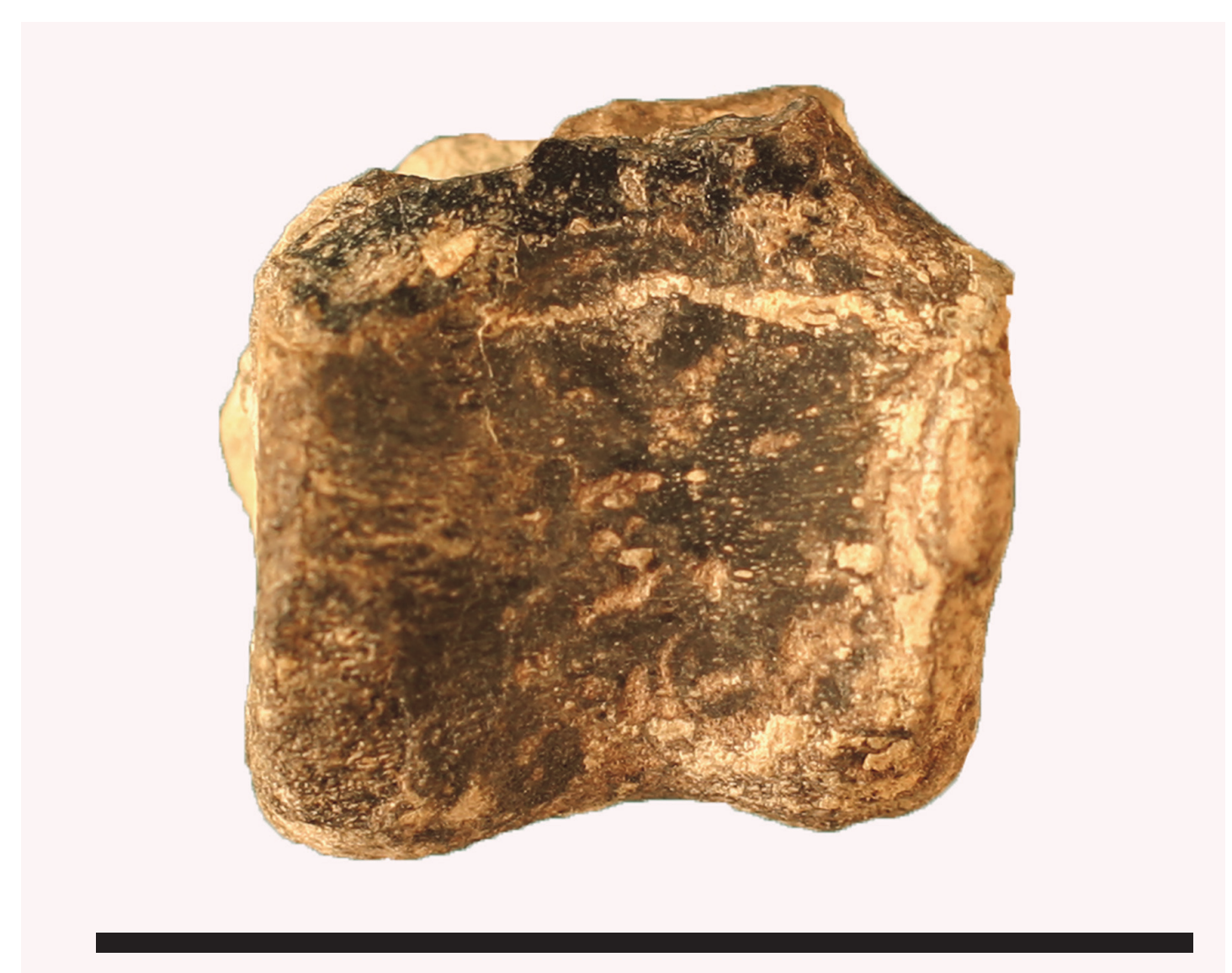

FIGURE 13. Examples of weathering stages of bones at the Aaron Scott Quarry. 13.1) Dryosaurus vertebra (VP 8612) with weathering stage 2. Note that the neural arch was broken prior to burial. Scale bar equals $5 \mathrm{~cm}$. 


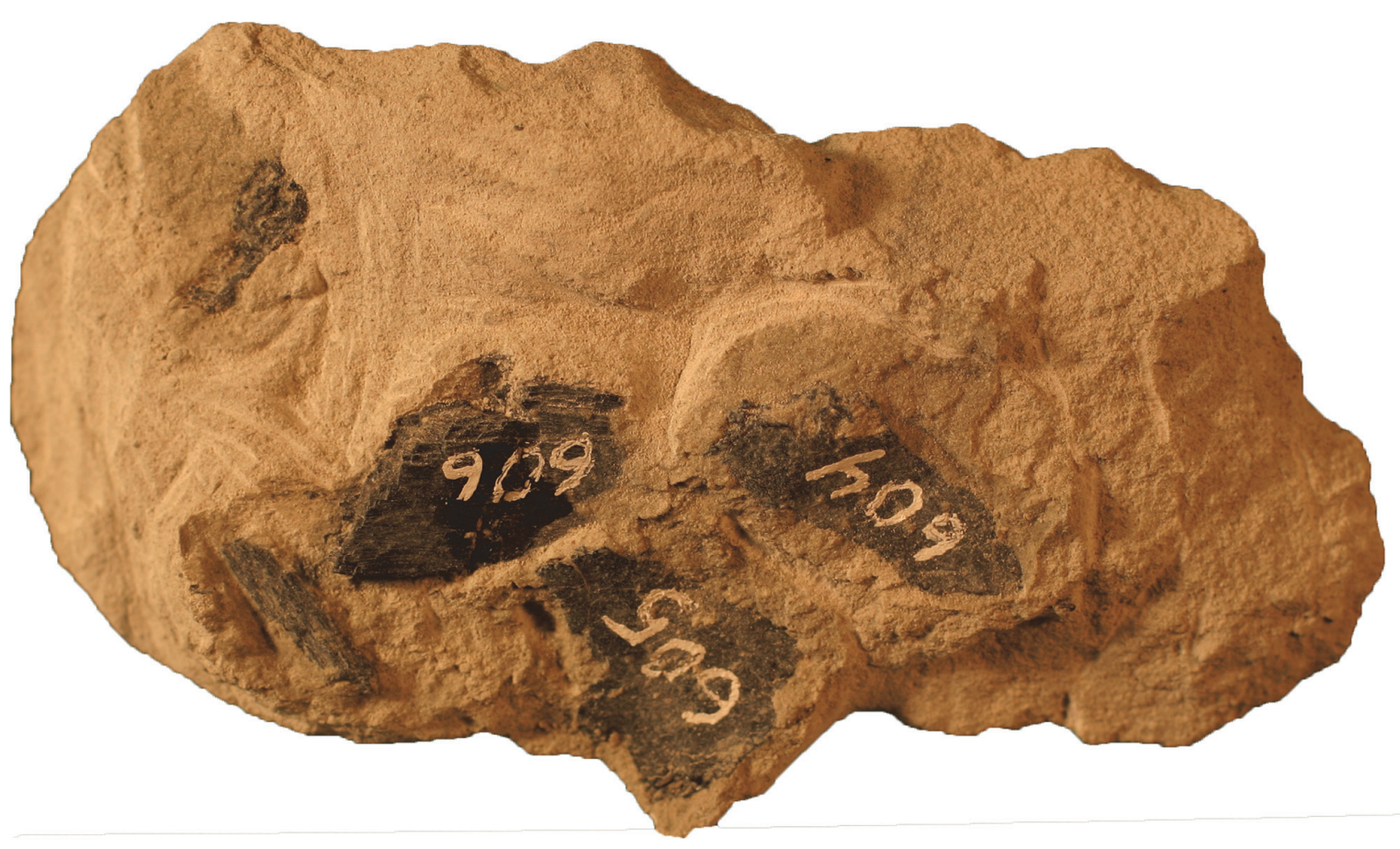

FIGURE 14. Fragments of bones (VP 8958) with weathering stage 5 . Scale bar equals $5 \mathrm{~cm}$.

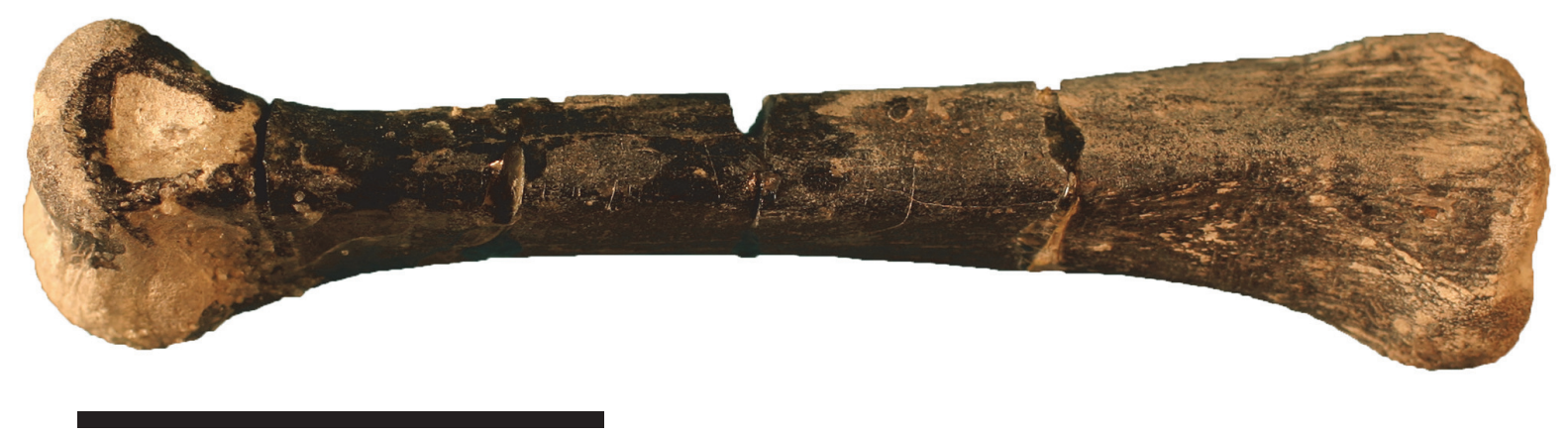

FIGURE 15. Allosaurus metatarsal (VP 8628) with weathering stage 0 . Scale bar equals $5 \mathrm{~cm}$.

entation, with one set trending west and a second set trending north-south. The current direction of the river feeding the delta is interpreted to be to the west, while wave activity along the margin of the lake oriented a second set of bones north-south, parallel to the shoreline. Turtles and crocodiles are present, indicating a perennial water source. Microfauna are also common and likely are easily transported by the fluvial currents. This calcite cemented siltstone represents a period of lake level rise, where freshwater conditions persist.
The presence of turtles and crocodiles in this layer is consistent with perennial freshwater conditions.

2. The sauropod and associated Allosaurus teeth lie on top of the calcite cemented layer, projecting up into the overlying mudstone. It is likely that these bones were deposited during the period of time when the freshwater lake levels were low. The bones of this layer are mostly disarticulated except several strings of sauropod vertebra. Other sauropod bones are associated with the vertebrae and are likely 


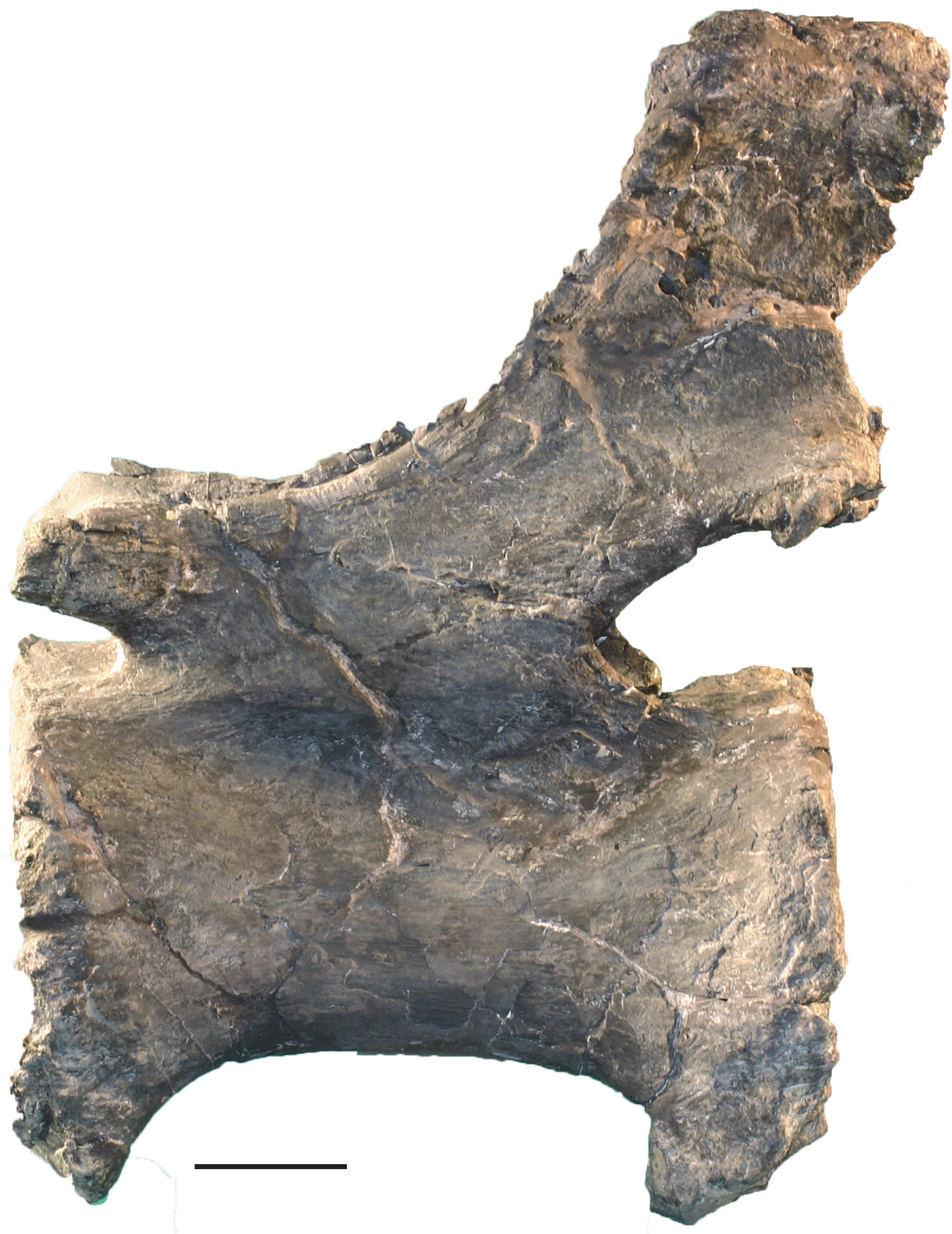

FIGURE 16. Barosaurus caudal vertebra (A. S. S. 772) with weathering stage 0 . Scale bar equals $5 \mathrm{~cm}$.' 
TABLE 6. Comparison of the Aaron Scott Quarry to the Huescar-1 locality, interpreted to be a fluvio-deltaic depositional setting. Red text indicates areas where the different examples match.

\begin{tabular}{|c|c|c|c|c|}
\hline & Aaron Scott Quarry & Huescar-1 & Los Rastras Formation Subenvironment C & Figures \\
\hline Sedimentology & $\begin{array}{l}\text { Basal siltstone with rip-up clasts; } \\
\text { calcareous siltstone; beds dipping } \\
\text { to the west; shale layer on top }\end{array}$ & $\begin{array}{l}\text { White calcareous silt beds, } \\
\text { detrital beds dipping to the } \\
\text { west }\end{array}$ & $\begin{array}{l}\text { Upward caorsening sequence characterized } \\
\text { by alternation of tabular-massive siltstone and } \\
\text { claystone interbedded with parallel laminated, } \\
\text { very fine grained sandstone. Sandstones with } \\
\text { current-ripples to horizontal lamination and } \\
\text { planar to trough cross-bedded in uppermost } \\
\text { coarse grained material }\end{array}$ & Fig. 4 \\
\hline Orientation & Slight preferential orientation & Slight preferential orientation & No bone orientation & Fig. 8,10 \\
\hline Taxonomy & $\begin{array}{l}\text { Abraded unidentified bones } \\
\text { common, semi-aquatic animals, } \\
\text { large herbivores common, } \\
\text { carnivore teeth, disarticulated } \\
\text { remains }\end{array}$ & $\begin{array}{l}\text { Abraded unidentified bones } \\
\text { common, semi-aquatic } \\
\text { animals, large herbivores } \\
\text { common, disarticulated } \\
\text { remains }\end{array}$ & $\begin{array}{l}\text { Abraded unidentified bones common, } \\
\text { articulated fish remains, plant debris, } \\
\text { conchostrans, bivalves, insects }\end{array}$ & Table 3, Fig. 9 \\
\hline Distribution & $\begin{array}{l}\text { Bones are densely concentrated } \\
\text { and uniformly distributed }\end{array}$ & $\begin{array}{l}\text { Bones are densely } \\
\text { concentrated and uniformly } \\
\text { distributed }\end{array}$ & Bones are densely concentrated & Fig. 4 \\
\hline Weathering & Average stage 2 & Average stage 2 & Stage $0-1$ & Fig. 11 \\
\hline Transport Groups & $\begin{array}{l}\text { Groups } 1 \text { and } 2 \text { dominant } \\
\text { (excluding teeth) }\end{array}$ & $\begin{array}{l}\text { Groups } 1 \text { and } 2 \text { dominant } \\
\text { (excluding teeth) }\end{array}$ & Groups 1 and 2 dominant & Fig. 6,9 \\
\hline
\end{tabular}

from the same animal. Allosaurus teeth are shed teeth left behind by the Allosaurus feeding on the remains of the sauropod. The bones in this horizon have a weathering stage of 0 , indicating that they were not exposed for a significant amount of time. The bones exhibit a slight bimodal orientation similar to the underlying layer, indicating the same fluvio-lacustrine processes acting on the bones.

3. Unionids are found in the overlying mudstone. This overlying mudstone represents rise in lake level, accompanied by an increase in fine clastic sedimentation into the lake.

The Aaron Scott bonebed accumulated on the surface of a lacustrine delta front (Figure 4, location $\mathrm{D}$ ) in an area subjected to reworking and abrasion as a result of fluvial transport. Dinosaurs and other animals congregated near the banks of the lake as smaller watering holes in the region dried. Bone locations and orientations indicate both fluvial and wave reorientation of the bones. Vertical distribution of the bones indicates that this accumulation occurred over a period of several years. When the drought ended, base level rose quickly, bones most recently deposited were best preserved, and a mudstone with an accumulation of clams buried the bone bed. Stratigraphic characteristics described in Jeffery et al. (2011) have concluded that the deposit in a delta facies. The observed taphonomic patterns may be characteristic of lacustrine deltas.
1. The bones consist of a mass attritional accumulation of several organisms that may have lived in or near the lake or the river, but were transported by the river after death. These organisms included terrestrial and semiaquatic fauna.

2. The accumulation is dominated by bones that have a high transport potential.

3. The bones are dominantly disarticulated, with the exception of some strings of vertebrae.

4. This indicates that the carcasses were exposed for a period of time allowing them to decay prior to transport.

5. The bones have a range of weathering stages from $0-5$, indicating that the bones were not all exposed at the same time but underwent a range of weathering times ranging from less than a month to six months.

6. There was a weak fluvial current that oriented some of the bones

7. down current, combined with wave activity that oriented some of the bones perpendicular to current.

8. Microfauna are common and likely accumulated due to transport by the fluvial system.

\section{ACKNOWLEDGEMENTS}

The site is currently being excavated under State of Utah Paleontological Excavation Permit 04-344 for locality number Em466V. We would like 
to acknowledge the work of Dr. D. Stone who led the initial group in the area and the late A. Scott who made the discovery. V. Freeman and F. Voner of Marietta College help to run the undergraduate field course and provide advice. G. Storrs at the Cincinnati Museum Center has been of assistance in providing facilities for curation and storage of material. J. Madsen, B. Britt and R. Sheetz provided advice, assistance and encouragement during field seasons. This work has been supported by funds from the Marietta College Department of Petroleum Engineering and Geology, Northern Kentucky University Department of Physics and Geology, the Northern Kentucky Center for Integrated Natural Science and Mathematics, the Northern Kentucky Greaves Summer Research Fellowship, the Northern Kentucky Student Undergraduate Research and Creativity Grant, the Northern Kentucky University Summer Faculty Research Grant, the Northern Kentucky University Faculty Project Grant and the National Science Foundation Kentucky EPSCoR program. Numerous students and volunteers have assisted in the collection, preparation and cataloging of the material collected from the site.

\section{REFERENCES}

Alberdi, M.T., Alonso, M.A., Azanza, B., Hoyos, M., and Morales, J. 2001. Vertebrate taphonomy in circumlake environments: three cases in the Guadix-Baza Basin (Granada, Spain). Paleogeography, Paleoclimatology, Paleoecology, 165:1-26.

Behrensmeyer, A.K. 1978. Taphonomic and ecologic information from bone weathering. Paleobiology, 4:150-162.

Behrensmeyer, A.K. 1982. Time resolution in fluvial vertebrate assemblages. Paleobiology, 8:211-227.

Bilbey, S.A. 1998. Cleveland-Lloyd Dinosaur Quarry Age, stratigraphy and depositional environments. Modern Geology, 22:87-120.

Carpenter, K., Chure, D.J., and Kirkland, J.I. (eds.). 1998. The Upper Jurassic Morrison Formation. An interdisciplinary study, Modern Geology, pt. 1, 22.

Carroll, A.R. 1998. Upper Permian lacustrine organic facies evolution, Southern Junggar Basin, NW China. Organic Geochemistry, 28:649-667.

Carroll, A.R. and Bohacs, K.M. 2001. Lake-type controls on petroleum source rock potential in nonmarine basins. American Association of Petroleum Geologists Bulletin, 85:1033-1053.

Coombs, W.P. Jr. 1975. Sauropod habits and habitats. Paleogeography, Paleoclimatology, Paleoecology, 17:1-33.
Dam, G. and Surlyk, Finn. 1992. Forced regressions in a large wave- and storm-dominated anoxic lake, Rhaetian-Sinemurian Kap Stewart Formation, East Greenland. Geology, 20, 749-752.

Demko, T.M., Currie, B.S., and Nicoll, K.A. 2004. Regional paleoclimatic and stratigraphic implications of paleosols and fluvial/overbank architecture in the Morrison Formation (Upper Jurassic), western interior, USA. Sedimentary Geology, 167:115-135.

Dodson, P., Behrensmeyer, A.K., Bakker, R.T., and Mclntosh, J.S. 1980. Taphonomy and paleoecology of the dinosaur beds of the Jurassic Morrison Formation. Paleobiology, 6:208-232.

Dunagan, S.P. 1998. Lacustrine and palustrine carbonates from the Morrison Formation (Upper Jurassic), east-central Colorado, USA: implications for depositional patterns, paleoecology, paleohydrology, and paleoclimatology. Unpublished PhD dissertation. University of Tennessee, Knoxville, TN, USA.

Dunagan, S.P. and Turner, C.E. 2004. Regional paleohydrologic and paleoclimatic setting of wetland/lacustrine depositional systems in the Morrison Formation (Upper Jurassic), Western Interior, USA. Sedimentary Geology, 167, 269-296.

Eberle, J.J. 2010. Seasonal variability in arctic temperatures during early Eocene time. Earth and Planet. Sci. Letters, 6p.

Engelmann, G.F., Chure, D.J., and Fiorillo, A.R. 2004. The implications of a dry climate for the paleoecology of the fauna of the Upper Jurassic Morrison Formation. Sedimentary Geology, 167:297-308.

Esker, D. 2009. An Analysis of the Morrison Formation's Terrestrial Faunal Diversity Across Disparate Environments of Deposition, Including the Aaron Scott Site Dinosaur Quarry in Central Utah. Unpublished MS Thesis, University of Cincinnati, Cincinnati, Ohio, USA.

Fiorillo, A.R. 1989. An experimental study of trampling, implications for the fossil record, p. 61-72. In Bonnischsen, R. and Sorg, M.H. (eds.), Bone Modification. Orono Center for the Study of the First Americans, University of Maine.

Foster, J.R. 2003. Paleoecological analysis of the vertebrate fauna of the Morrison Formation (Upper Jurassic), Rocky Mountain Region, USA. New Mexico Museum of Natural History and Science Bulletin, 23.

Frison, G.C. and Todd, L.C. 1986. Taphonomy and archaeology of a Clovis kill in northern Wyoming. University of New Mexico Press.

Gates, T.A. 2005. The Late Jurassic Cleveland-Lloyd Dinosaur Quarry as a drought-induced assemblage. Palaois, 20:363-375.

Gillette, D.D. (ed.). 1999. Vertebrate paleontology of Utah. Geological Survey of Utah Miscellaneous Publication, 99-1. 
Hunt, A.P., Lucas, S.G., Krainer, K., and Spielman, J. 2006. The taphonomy of the Cleveland-Lloyd dinosaur quarry, Upper Jurassic Morrison Formation, Utah, a re-evaluation. Bulletin, New Mexico Museum of Natural History and Science, 38:57-65.

Jackson, T.J. 1979. Lacustrine deltaic deposition of the Jurassic Morrison Formation of north-central Colorado, p. 31-54. In Ethridge, F. (Ed) Field guide, northern Front Range and Northwest Denver Basin, Colorado, Colorado State University Dep. Earth Resour., 24: 31-54.

Jeffery, D.L, Bertog, J.L., and Bishop, J.R. 2011. Small scale fluvio-deltaic stratal relationships of a dinosaur accumulation at the Aaron Scott Quarry, Morrion Formation. Palaois, 26:275-283.

Keighley, D., Flint, S., Howell, J., and Moscariello, A. 2003. Sequence stratigraphy in lacustrine basins: A model for part of the Green River Formation (Eocene), southwest Uinta Basin, Utah, USA. Journal of Sedimentary Research, 73:987-1006.

Kirkland, J.I. 2006. Fruita Paleontological Area (Upper Jurassic, Morrison Formation), Western Colorado: An example of terrestrial taphofacies analysis, p. 6795. In Foster, J.R. and Lucas, S.G. (eds.), Paleontology and Geology of the Upper Jurassic Formation, New Mexico Museum of Natural History and Science Bulletin, 36:67-95.

Kirkland, J.I. and Armstrong, H.J. 1992. Taphonomy of the Mygatt-Moore Quarry, Middle Brush Basin Member, Morrison Formation (Upper Jurassic) Western Colorado. Journal of Vertebrate Paleontology, 12(3S):40A.

Lockley, M.G., Houck, K.J., and Prince, N.K. 1986. North America's largest dinosaur trackway site: Implications for Morrison Formation paleoecology. Geological Society of America Bulletin, 10, 1163-1176.

Mancuso, A.C. and Marsicano, C.A. 2008. Paleoenvironments and taphonomy of a Triassic lacustrine system (Los Rastros Formation, central-western Argentina. Palaois, 23:535-547.

Myers, T. 2007. Taphonomy of the Mother's Day Quarry, Upper Jurassic Morrison Formation, south-central Montana. Palaois, 22:651-666.

Oviatt, C.G., McCoy, W.D., and Nash, W.P. 1994. Sequence Stratigraphy of lacustrine deposits: A Quaternary example from the Bonneville basin, Utah. Geological Society of America Bulletin, 106:133-144.

Parrish, J.T., Peterson, F., and Turner, C.E. 2004. Jurassic "savannah" - plant taphonomy and climate of the Morrison Formation (Upper Jurassic, western USA). Sedimentary Geology, 167:137-162.
Peterson, F. 1994. Sand dunes, sabkhas, streams and shallow seas: Jurassic paleogeography in the southern part of the Western Interior Basin, p. 233-272.In Caputa, M. V., Peterson, J. A., Franczyk, K. J. (Eds) Mesozoic systems of the Rocky Mountain Region, USA, Society for Sedimentary Geology, Denver, CO, 233-272.

Peterson, F. and Turner-Peterson, C.E. 1987. The Morrison Formation of the Colorado Plateau - Recent advances in sedimentology, stratigraphy, and paleotectonics. Hunteria, 2:1-17.

Richmond, D.R. and Morris, T.H. 1998. Stratigraphy and cataclysmic deposition of the Dry Mesa Dinosaur Quarry, Mesa County, Colorado. Modern Geology, 22:121-143.

Rogers, R.R. 1990. Taphonomy of three dinosaur bone beds in the Upper Cretaceous Two Medicine Formation of northwest Montana: Evidence for droughtrelated mortality. Palaois, 5, 394-413.

Rogers, R.R., Arcucci, A.B., Abdala, F., Sereno, P.C., Forester, C.A., and May, C.L. 2001. Paleoenvironment and taphonomy of the Chanares Formation tetrapod assemblage (Middle Triassic), Northwestern Argentina: Spectacular preservation in volcanogenic concretions. Palaois, 16, 461-481.

Steiner, M.B. 1998. Age, correlation and tectonic implications of Morrison Formation paleomagnetic data, including rotation of the Colorado Plateau. Modern Geology, 22:261-281.

Stokes, W.L. 1986. Geology of Utah. Utah Museum of Natural History Occasional Paper, 6.

Turner, C.E. and Peterson, F. 2004. Reconstruction of the Upper Jurassic Morrison Formation extinct ecosystem - a synthesis. Sedimentary Geology, 167:309-355.

Turner, C.E., Peterson, F., and Dunagan, S.P. 2004. Reconstruction of the extinct ecosystem of the Upper Jurassic Morrison Formation. Sedimentary Geology, 167:111-113.

US Census Bureau. 2000. Outline map of Utah and Counties downloaded July 2013. US Bureau of Census 2000 Utah G-1. www.netstate.com/states/maps/ ut_maps.htm.

Vande-Velde, D.M. 2006. Interpretation of the depositional environment and paleoclimate of dinosaur sites, Brushy Basin Member of the Jurassic Morrison Formation, East-central Utah. Unpublished MS Thesis, Bowling Green State University.

Voorhies, M.R. 1969. Taphonomy and population dynamics of an early Pliocene

vertebrate fauna, Knox County, Nebraska. Contributions to Geology of the University of Wyoming Special Paper, 1:1-69. 